\title{
Chloroplast in Plant-Virus Interaction
}

\author{
Jinping Zhao ${ }^{1,2}$, Xian Zhang ${ }^{3}$, Yiguo Hong $^{3}$ and Yule Liu ${ }^{1 *}$ \\ ${ }^{1}$ MOE Key Laboratory of Bioinformatics, Center for Plant Biology, Tsinghua-Peking Joint Center for Life Sciences, School of \\ Life Sciences, Tsinghua University, Beijing, China, ${ }^{2}$ State Key Laboratory Breeding Base for Sustainable Control of Pest and \\ Disease, Key Laboratory of Biotechnology in Plant Protection, Institute of Virology and Biotechnology, Zhejiang Academy of \\ Agricultural Sciences, Hangzhou, China, ${ }^{3}$ Research Centre for Plant RNA Signaling, School of Life and Environmental \\ Sciences, Hangzhou Normal University, Hangzhou, China
}

\section{OPEN ACCESS}

Edited by:

Nobuhiro Suzuki,

Okayama University, Japan

Reviewed by:

Hideki Takahashi,

Tohoku University, Japan

Ricardo Flores,

Polytechnic University of Valencia,

Spain

Hanako Shimura,

Hokkaido University, Japan

*Correspondence:

Yule Liu

yuleliu@mail.tsinghua.edu.cn

Specialty section:

This article was submitted to

Virology,

a section of the journal

Frontiers in Microbiology

Received: 15 July 2016

Accepted: 20 September 2016

Published: 04 October 2016

Citation:

Zhao J, Zhang $X$, Hong Y and Liu Y

(2016) Chloroplast in Plant-Virus Interaction. Front. Microbiol. 7:1565.

doi: 10.3389/fmicb.2016.01565
In plants, the chloroplast is the organelle that conducts photosynthesis. It has been known that chloroplast is involved in virus infection of plants for approximate 70 years. Recently, the subject of chloroplast-virus interplay is getting more and more attention. In this article we discuss the different aspects of chloroplast-virus interaction into three sections: the effect of virus infection on the structure and function of chloroplast, the role of chloroplast in virus infection cycle, and the function of chloroplast in host defense against viruses. In particular, we focus on the characterization of chloroplast protein-viral protein interactions that underlie the interplay between chloroplast and virus. It can be summarized that chloroplast is a common target of plant viruses for viral pathogenesis or propagation; and conversely, chloroplast and its components also can play active roles in plant defense against viruses. Chloroplast photosynthesis-related genes/proteins (CPRGs/CPRPs) are suggested to play a central role during the complex chloroplast-virus interaction.

\section{Keywords: chloroplast, plant virus, protein interaction, virus infection, plant defense}

\section{INTRODUCTION}

Plant viruses, as obligate biotrophic pathogens, attack a broad range of plant species utilizing host plants' cellular apparatuses for protein synthesis, genome replication and intercellular and systemic movement in order to support their propagation and proliferation. Virus infection usually causes symptoms resulting in morphological and physiological alterations of the infected plant hosts, which always incurs inferior performance such as the decreased host biomass and crop yield loss.

Abbreviations: AbMV, Abutilon mosaic virus; AltMV, Alternanthera mosaic virus; AMV, Alfalfa mosaic virus; BaMV, Bamboo mosaic virus; BSMV, Barley stripe mosaic virus; CaMV, Cauliflower mosaic virus; CI protein, Cylindrical inclusion protein; CMV, Cucumber mosaic virus; CNV, Cucumber necrosis virus; CP, Coat protein, Capsid protein; CPRG/CPRP, chloroplast photosynthesis-related gene/protein; HC-Pro, Helper component protein proteinase; JA, Jasmonic acid; MDMV, Maize dwarf mosaic virus; MP, Movement protein; OEC, Oxygen evolving complex; OYDV, Onion yellow dwarf virus; PD, plasmodesmata; PMTV, Potato mop-top virus; PPV, Plum pox virus; PS II, photosystem II; PVX, Potato virus X; PVY, Potato virus Y; RCNMV, Red clover necrotic mosaic virus; RdRP, RNA-dependent RNA polymerase; $R$ gene, Resistance gene; ROS, Reactive oxygen species; RSV, Rice stripe virus; RuBisCO, Ribulose-1,5-bisphosphate carboxylase/oxygenase; RYMV, Rice yellow mottle virus; SA, Salicylic acid; SCMV, Sugarcane mosaic virus; siRNA, small interfering RNA; SMV, Soybean mosaic virus; SNARE, soluble NSF attachment protein receptor; SYSV, Shallot yellow stripe virus; TBSV, Tomato bushy stunt virus; TEV, Tobacco etch virus; TGB proteins, Triple gene block proteins; TMV, Tobacco mosaic virus; TNV, Tobacco necrosis virus; ToMV, Tomato mosaic virus; TRSV, Tobacco ringspot virus; TuMV, Turnip mosaic virus; TVMV, Tobacco vein-mottling virus; TYMV, Turnip yellow mosaic virus; VRC, Viral replication complex; WMV, Watermelon mosaic virus. 
The most common viral symptom is leaf chlorosis, reflecting altered pigmentation and structural change of chloroplasts. Viral influence on chloroplast structures and functions usually leads to depleted photosynthetic activity. Since the first half of the twentieth century, an increasing number of reports on a broad range of plant-virus combinations have revealed that virus infection inhibits host photosynthesis, which is usually associated with viral symptoms (Kupeevicz, 1947; Owen, 1957a,b, 1958; Hall and Loomis, 1972; Mandahar and Garg, 1972; Reinero and Beachy, 1989; Balachandran et al., 1994b; Herbers et al., 2000; Rahoutei et al., 2000; Guo et al., 2005; Christov et al., 2007; Kyseláková et al., 2011). It is suggested that modification of photosynthesis is a common and conserved strategy for virus pathogenesis to facilitate infection and to establish an optimal niche (Gunasinghe and Berger, 1991). The disturbance of chloroplast components and functions may be responsible for the production of chlorosis symptoms that are associated with virus infection (Manfre et al., 2011).

A series of typical changes followed by chlorotic symptoms imply the occurrence of chloroplast-virus interactions. These changes include (1) fluctuation of chlorophyll fluorescence and reduced chlorophyll pigmentation (Balachandran et al., 1994a), (2) inhibited photosystem efficiency (Lehto et al., 2003), (3) imbalanced accumulation of photoassimilates (Lucas et al., 1993; Olesinski et al., 1995, 1996; Almon et al., 1997), (4) changes in chloroplast structures and functions (Bhat et al., 2013; Otulak et al., 2015), and (5) repressed expression of nuclear-encoded chloroplast and photosynthesis-related genes (CPRGs) (Dardick, 2007; Mochizuki et al., 2014a), (6) direct binding of viral components with chloroplast factors (Shi et al., 2007; Bhat et al., 2013; Zhao et al., 2013).

In fact, the chloroplast itself is a chimera of components of various origins coming from its bacterial ancestors, viruses and host plants. For example, chloroplast contains the nuclearencoded phage T3/T7-like RNA polymerase (Hedtke et al., 1997; Kobayashi et al., 2001; Filée and Forterre, 2005). It is not surprising that chloroplast has an important role in plant-virus interactions. Indeed, more and more chloroplast factors have been identified to interact with viral components (Table 1). These factors are involved in virus replication, movement, symptoms or plant defense, suggesting that viruses have evolved to interact with chloroplast.

In this review, we focus on the topic of how chloroplast factors and viral components interact with each other and how these interactions contribute to viral pathogenesis and symptom development, especially in virus-susceptible hosts.

\section{CHLOROPLAST IS INVOLVED IN VIRAL SYMPTOM PRODUCTION}

Although the development of viral symptoms can be traced back to different causes, the disruption of normal chloroplast function has been suggested to cause typical photosynthesisrelated symptoms, such as chlorosis and mosaic (Rahoutei et al., 2000). Chloroplast has been implicated as a common target of plant viruses for a long time. For instance, the severe chlorosis on systemic leaves infected by CMV in Nicotiana tabacum cv. Xanthi nc is associated with size-reduced chloroplasts containing fewer grana (Roberts and Wood, 1982). A second example shows that the leaf mosaic pattern caused by virus infection can be due to the layout of clustered mesophyll cells in which chloroplasts were damaged to various degrees (Almási et al., 2001). A third example shows that symptom caused by PVY infection is often associated with decrease in the number and size of host plant chloroplasts as well as inhibited photosynthesis (Pompe-Novak et al., 2001). Based on the current studies, the ultrastructural alteration of chloroplast and the reduced abundance of proteins involved in photosynthesis are the two main causes of virus induced chloroplast symptomatology (see below).

\section{Effect of Virus Infection on Chloroplast Structure}

Successions of analysis on the ultrastructural organization of plant cells infected with viruses have been performed with electron microscopy since the 1940s. There is a stunning convergence among different host-virus systems where significant alteration or rearrangement of the chloroplast ultrastructure is correlated with the symptom development (Bald, 1948; Arnott et al., 1969; Ushiyama and Matthews, 1970; Allen, 1972; Liu and Boyle, 1972; Mohamed, 1973; Moline, 1973; Appiano et al., 1978; Tomlinson and Webb, 1978; SchuchalterEicke and Jeske, 1983; Bassi et al., 1985; Choi, 1996; Mahgoub et al., 1997; Xu and Feng, 1998; Musetti et al., 2002; Zechmann et al., 2003; Guo et al., 2004; El Fattah et al., 2005; Schnablová et al., 2005; Li et al., 2006; Yan et al., 2008; Laliberté and Sanfaçon, 2010; Montasser and Al-Ajmy, 2015; Zarzyńska-Nowak et al., 2015; Zhao et al., 2016). The chloroplast malformations include (1) overall decrease of chloroplast numbers and chloroplast clustering; (2) atypical appearance of chloroplast, such as swollen or globule chloroplast, chloroplast with membranebound extrusions or amoeboid-shaped chloroplast, generation of stromule (a type of dynamic tubular extensions from chloroplast); (3) irregular out-membrane structures such as peripheral vesicle, cytoplasmic invagination, membrane proliferations and broken envelope; (4) changes of content inside the chloroplast such as small vesicles or vacuoles in stroma, large inter-membranous sac, numerous, and/or enlarged starch grains, increase in the number and size of electron-dense granules/plastoglobules/bodies; (5) unusual photosynthetic structures such as disappearance of grana stacks, distorted, loosen, or dilated thylakoid and the disappearance of stroma; and (6) completely destroyed chloroplasts and disorganized grana scattering into the cytoplasm. In these studies, the viruses are from 12 families and have either sense ssRNA, antisense ssRNA or ssDNA genomes, covering the majority of genera and including those responsible for devastating disease. This implies that chloroplast abnormality is a common event across diverse plant-virus interactions. The types of chloroplast abnormalities caused by virus infection are summarized in Table 2 and schemed in Figure 1. 
TABLE 1 | Chloroplast factors interacting with virus nucleic acids or proteins.

\begin{tabular}{|c|c|c|c|c|c|}
\hline Plant Virus $^{\star}$ & Virus components & $\begin{array}{l}\text { Chloroplast } \\
\text { factors }\end{array}$ & $\begin{array}{l}\text { Subcellular } \\
\text { localization }\end{array}$ & Biological process & References \\
\hline \multicolumn{6}{|c|}{ SsRNA POSITIVE-STRAND VIRUSES } \\
\hline \multicolumn{6}{|l|}{ Potexvirus/Alphaflexiviridae } \\
\hline \multirow[t]{2}{*}{$\begin{array}{l}\text { Alternanthera mosaic virus } \\
\text { (AltMV) }\end{array}$} & TGB3 & $\begin{array}{l}\text { Chloroplast } \\
\text { membrane }\end{array}$ & Chloroplast & $\begin{array}{l}\text { Cell-to-cell movement, } \\
\text { long-distance movement, } \\
\text { symptom }\end{array}$ & Lim et al., 2010 \\
\hline & & PsbO & Surrounding chloroplast & Symptom & Jang et al., 2013 \\
\hline Bamboo mosaic virus (BaMV) & RNA 3' UTR & cPGK & Chloroplast Cytoplasm, & Replication & Cheng et al., 2013 \\
\hline Potato virus $X(P V X)$ & $\mathrm{CP}$ & Plastocyanin & Chloroplast & Symptom & Qiao et al., 2009 \\
\hline \multicolumn{6}{|l|}{ Alfamovirus/Bromoviridae } \\
\hline Alfalfa mosaic virus (AMV) & $\mathrm{CP}$ & PsbP & Cytoplasm & Replication & $\begin{array}{l}\text { Balasubramaniam et al., } \\
2014\end{array}$ \\
\hline \multicolumn{6}{|l|}{ Cucumovirus/Bromoviridae } \\
\hline Cucumber mosaic virus (CMV) & $1 a, 2 a$ & Tsip1 & Cytoplasm & Replication & Huh et al., 2011 \\
\hline $\begin{array}{l}\text { Cucumber mosaic virus Y strain } \\
\text { satellite RNA (CMV-Y-sat) }\end{array}$ & 22-nt vsiRNA ${ }^{\star \star}$ & ChIl mRNA & Cytoplasm & Symptom & $\begin{array}{l}\text { Shimura et al., } 2011 \text {; } \\
\text { Smith et al., } 2011\end{array}$ \\
\hline \multicolumn{6}{|l|}{ Potyvirus/Potyviridae } \\
\hline \multirow[t]{3}{*}{ Potato virus Y (PVY) } & $\mathrm{CP}$ & $\mathrm{RbCL}$ & - & Symptom & Feki et al., 2005 \\
\hline & HC-Pro & MinD & Cytoplasm & Symptom & Jin et al., 2007 \\
\hline & & CF1 $\beta$ & Chloroplast & Symptom & \\
\hline Onion yellow dwarf virus (OYDV) & P3 & $\mathrm{RbCL}, \mathrm{RbCS}$ & - & - & Lin et al., 2011 \\
\hline Plum pox virus (PPV) & $\mathrm{Cl}$ & Psak & - & Host defense & Jimenez et al., 2006 \\
\hline Sugarcane mosaic virus (SCMV) & HC-Pro & Fd V & Cytoplasm & Symptom & Cheng et al., 2008 \\
\hline \multirow[t]{2}{*}{ Soybean mosaic virus (SMV) } & P1 & Rieske Fe/S & - & Symptom & Shi et al., 2007 \\
\hline & P3 & $\mathrm{RbCL}, \mathrm{RbCS}$ & - & - & Lin et al., 2011 \\
\hline Shallot yellow stripe virus (SYSV) & P3 & $\mathrm{RbCL}, \mathrm{RbCS}$ & - & - & Lin et al., 2011 \\
\hline \multirow[t]{2}{*}{ Turnip mosaic virus (TuMV) } & $\mathrm{CP}$ & 37-kD protein & - & - & McClintock et al., 1998 \\
\hline & P3 & $\mathrm{RbCL}, \mathrm{RbCS}$ & - & - & Lin et al., 2011 \\
\hline $\begin{array}{l}\text { Tobacco vein-mottling virus } \\
\text { (TVMV) }\end{array}$ & $\mathrm{Cl}$ & Psak & - & Host defense & Jimenez et al., 2006 \\
\hline \multicolumn{6}{|l|}{ Dianthovirus/Tombusviridae } \\
\hline $\begin{array}{l}\text { Red clover necrotic mosaic virus } \\
\text { (RCNMV) }\end{array}$ & MP & GAPDH-A & $\begin{array}{l}\text { Chloroplast, } \\
\text { Endoplasmic reticulum }\end{array}$ & Cell-to-cell movement & Kaido et al., 2014 \\
\hline \multicolumn{6}{|l|}{ Pomovirus/Virgaviridae } \\
\hline Potato mop-top virus (PMTV) & TGB2 & Chloroplast lipid & Chloroplast & Replication & Cowan et al., 2012 \\
\hline \multicolumn{6}{|l|}{ Tobamovirus/Virgaviridae } \\
\hline \multirow[t]{5}{*}{ Tobacco mosaic virus (TMV) } & $126 \mathrm{~K}$ replicase & PsbO & - & Host defense & Abbink et al., 2002 \\
\hline & & NRIP & Cytoplasm, Nucleus & Host defense & Caplan et al., 2008 \\
\hline & 126 K/183 K replicase & AtpC & VRCs & Host defense & Bhat et al., 2013 \\
\hline & & $\mathrm{RCA}$ & VRCs & & Host defense \\
\hline & MP & $\mathrm{RbCS}$ & Cytoplasm & Cell-to-cell movement & Zhao et al., 2013 \\
\hline \multirow[t]{3}{*}{ Tomato mosaic virus (ToMV) } & $\mathrm{CP}$ & FdI & Cytoplasm & Symptom & $\begin{array}{l}\text { Sun et al., 2013; Ma } \\
\text { et al., } 2008\end{array}$ \\
\hline & & IP-L & Thylakoid membrane & Long distance movement & $\begin{array}{l}\text { Li et al., 2005; Zhang } \\
\text { et al., } 2008\end{array}$ \\
\hline & MP & $\mathrm{RbCS}$ & Cytoplasm & Cell-to-cell movement & Zhao et al., 2013 \\
\hline \multicolumn{6}{|c|}{ SSRNA NEGATIVE SENSE VIRUSES } \\
\hline \multicolumn{6}{|l|}{ Tenuivirus/Unassigned } \\
\hline Rice stripe virus (RSV) & $\mathrm{SP}$ & PsbP & Cytoplasm & Symptom & Kong et al., 2014 \\
\hline
\end{tabular}


TABLE 1 | Continued

\begin{tabular}{|c|c|c|c|c|c|}
\hline Plant Virus ${ }^{\star}$ & Virus components & $\begin{array}{l}\text { Chloroplast } \\
\text { factors }\end{array}$ & $\begin{array}{l}\text { Subcellular } \\
\text { localization }\end{array}$ & Biological process & References \\
\hline \multicolumn{6}{|l|}{ SSDNA VIRUSES } \\
\hline \multicolumn{6}{|l|}{ Begomovirus/Geminiviridae } \\
\hline Abutilon mosaic virus (AbMV) & MP & cpHSC70-1 & $\begin{array}{l}\text { Cell periphery, } \\
\text { Chloroplast }\end{array}$ & Cell-to-cell movement & Krenz et al., 2010, 2012 \\
\hline \multicolumn{6}{|l|}{ dsDNA VIRUSES } \\
\hline \multicolumn{6}{|l|}{ Caulimovirus/Caulimoviridae } \\
\hline Cauliflower mosaic virus (CaMV) & P6 & CHUP1 & VRCs & Cell-to-cell movement & Angel et al., 2013 \\
\hline
\end{tabular}

*Virus taxonomy is in format of Genus/Family. ${ }^{*}$ Virus-derived small interfering RNA. - Not addressed. ssRNA, single-stranded RNA; ssDNA, single-stranded DNA.

\section{Viral Effectors Are Related to the Chloroplast Structural Changes}

Recent reports have revealed that viral factors, especially coat proteins (CPs), affect chloroplast ultrastructure and symptom development (see below).

Viral coat proteins (CPs) have been demonstrated as determinants of symptom phenotypes for a much long period (Heaton et al., 1991; Neeleman et al., 1991). The earlier research showed that virion-like particles or virus inclusion in chloroplast are positively related to the development of mosaic symptom caused by TMV (Bald, 1948; Shalla, 1964). The more virion-like particles accumulated in chloroplast, the more severe morphological defects of chloroplast structure occurred (Matsushita, 1965; Shalla, 1968; Granett and Shalla, 1970; Betto et al., 1972). Later researches indicate that virion-like particles in chloroplast are pseudovirions, in which chloroplast transcripts are encapsidated by TMV CPs (Shalla et al., 1975; Rochon and Siegel, 1984; Atreya and Siegel, 1989), highlighting the involvement of CPs in the alteration of chloroplast ultrastructure. TMV CP does not possess a classical chloroplast transit peptide (TP) but can be imported into chloroplast effectively in a ATP-independent mode (Banerjee and Zaitlin, 1992). The majority of TMV CPs in chloroplasts are associated with the thylakoid membranes in systemically invaded N. tabacum leaves (Reinero and Beachy, 1986; Hodgson et al., 1989). Various natural TMV mutants, whose CPs excessively accumulate in chloroplast, always induce more severe symptoms and aggravated inhibition of the PS II activity (Regenmortel and FraenkelConrat, 1986; Reinero and Beachy, 1986, 1989; Banerjee et al., 1995; Lehto et al., 2003), suggesting that chloroplasttargeted CPs act as the inducer of chloroplast ultrastructure rearrangements (Figure 1, Table 2). Tobamovirus CP can bind tobacco chloroplast Ferredoxin I (Fd I) (Sun et al., 2013, Table 1), while TMV infection reduces the protein level of Fd I in tobacco leaves ( $\mathrm{Ma}$ et al., 2008). Silencing of Fd1 in tobacco plants leads to symptomatic chlorosis phenotype and enhances CP accumulation in chloroplast as well as virus multiplication, suggesting that the CP-Fd I interaction may contribute to the development of chlorosis and mosaic symptoms.

PVX CP and viral particles can also be detected in chloroplast of the infected plants, causing structural alteration of chloroplast membranes and grana stacks (Kozar and Sheludko, 1969; Qiao et al., 2009). PVX CP interacts with the chloroplast TP of plastocyanin (Table 1), and silencing of plastocyanin in $N$. benthamiana reduces viral symptom severity. In plastocyanin silenced plants, the accumulation of CP in chloroplasts was also reduced although total $\mathrm{CP}$ amount in infected cells did not change (Qiao et al., 2009), suggesting that the CP-plastocyanin interaction positively contributes to viral symptom-associated chloroplast abnormality (Figure 1, Table 2).

PVY CP is preferentially associated with the thylakoid membranes (Gunasinghe and Berger, 1991). PVY CP interacts with the large subunits of RuBisCO (RbCL) (Table 1) and this interaction may be involved in the production of mosaic and chlorosis symptoms (Feki et al., 2005). Further research indicates that chloroplast-targeted, but not cytosol-localized CP induces virus-like symptom (Naderi and Berger, 1997a,b). These observations suggest an intimate relationship between chloroplasts and PVY CP during the process of inhibiting PS II in viral pathogenesis.

CMV infection causes symptoms associated with chloroplast ultrastructure changes (Roberts and Wood, 1982; Shintaku et al., 1992; Mazidah et al., 2012). CMV CP can be transported into intact chloroplast promptly in a ATP-independent mode and the amount of CP into chloroplast correlated with the severity of mosaic symptoms (Liang et al., 1998). The single amino acid substitution at residue 129 in CP of CMV pepo strain is found to induce chloroplast abnormalities (Figure 1, Table 2) associated with the alteration of chlorosis severity (Shintaku et al., 1992; Suzuki et al., 1995; Mochizuki and Ohki, 2011; Mochizuki et al., 2014b), suggesting that CMV CP alone possess the virulence to induce chlorosis and chloroplast abnormalities in CMV-infected tobacco plants (Mochizuki and Ohki, 2011; Mochizuki et al., 2014b).

Viral CPs could also impose virulent effects from outside of the chloroplasts. A series of CP deletion mutants of TMV (Lindbeck et al., 1991) and ToMV spontaneous mutant ToMV$\mathrm{L}_{11} \mathrm{Y}$ (Ohnishi et al., 2009) causes severe chlorosis associated with severe deformation and disruption of chloroplasts and the mutant CPs are shown to contribute to this severe chlorosis (Lindbeck et al., 1991; Ohnishi et al., 2009). Because the mutant CPs aggregate outside of chloroplasts, they may subvert the chloroplast development and cause the degradation of 
TABLE 2 | Structural changes of chloroplasts induced by virus infection.

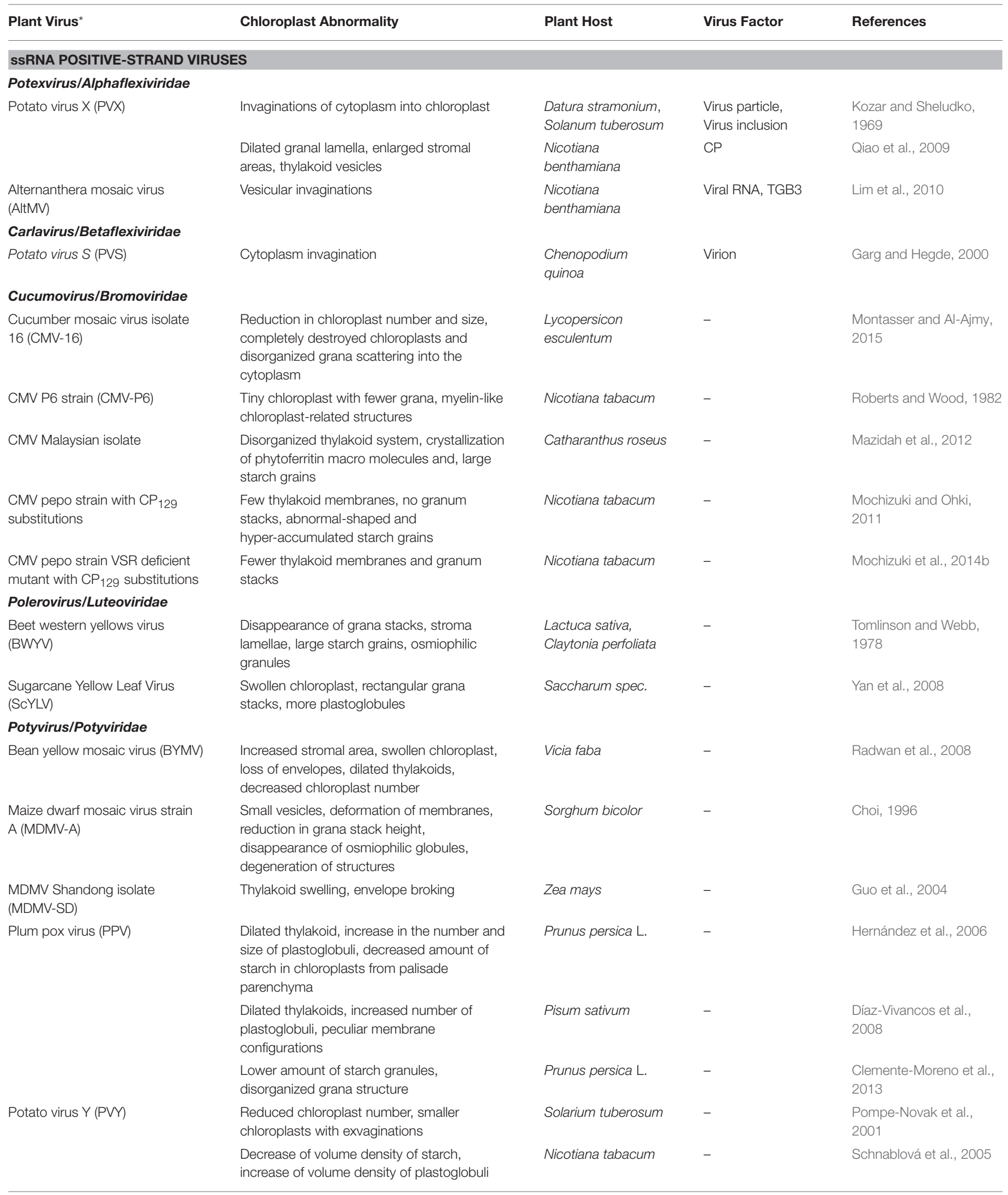


TABLE 2 | Continued

\begin{tabular}{|c|c|c|c|c|}
\hline Plant Virus* & Chloroplast Abnormality & Plant Host & Virus Factor & References \\
\hline Sugarcane mosaic virus (SCMV) & $\begin{array}{l}\text { Swollen chloroplast, increased number of } \\
\text { plastoglobuli }\end{array}$ & Sorghum bicolor & - & El Fattah et al., 2005 \\
\hline Turnip mosaic Virus (TuMV) & $\begin{array}{l}\text { Chloroplast aggregation, irregular shaped } \\
\text { chloroplast, large osmiophilic granules, poorly } \\
\text { developed lamellar system, few or no starch } \\
\text { grains, }\end{array}$ & $\begin{array}{l}\text { Chenopodium } \\
\text { quinoa }\end{array}$ & Virus particle & Kitajima and Costa, 1973 \\
\hline $\begin{array}{l}\text { Zucchini yellow mosaic virus } \\
\text { (ZYMV) }\end{array}$ & $\begin{array}{l}\text { Decrease of chloroplasts amount, decreased } \\
\text { thylakoids, increased plasto-globule and } \\
\text { starch grain in chloroplast }\end{array}$ & Cucurbita pepo & - & Zechmann et al., 2003 \\
\hline \multicolumn{5}{|l|}{ Fijivirus/Reoviridae } \\
\hline \multirow[t]{2}{*}{ Maize rough dwarf virus (MRDV) } & $\begin{array}{l}\text { Membrane disappearance, swollen grana } \\
\text { discs, periphery vesicles }\end{array}$ & Zea mays & Virus particle & Gerola and Bassi, 1966 \\
\hline & Distorted grana and paired membranes. & $\begin{array}{l}\text { Chenopodium } \\
\text { quinoa }\end{array}$ & Virus particle & Martelli and Russo, 1973 \\
\hline \multicolumn{5}{|l|}{ Fabavirus/Secoviridae } \\
\hline $\begin{array}{l}\text { Broad bean wilt virus } 2 \text { (BBWV-2) } \\
\text { isolate B935 }\end{array}$ & $\begin{array}{l}\text { Inhibited lamellar development, membrane } \\
\text { vesiculation }\end{array}$ & Vicia faba & - & Li et al., 2006 \\
\hline BBWV-2 isolate PV131 & $\begin{array}{l}\text { Chloroplast with swollen or disintegrated } \\
\text { membrane }\end{array}$ & Vicia faba & - & \\
\hline \multicolumn{5}{|l|}{ Tombusvirus/Tombusviridae } \\
\hline $\begin{array}{l}\text { Artichoke mottled crinkle virus } \\
\text { (AMCV) }\end{array}$ & Distorted grana and paired membranes. & $\begin{array}{l}\text { Chenopodium } \\
\text { quinoa }\end{array}$ & Virus particle & Martelli and Russo, 1973 \\
\hline \multirow[t]{2}{*}{ Tomato bushy stunt virus (TBSV) } & $\begin{array}{l}\text { Large plastidial vacuole, disorganized lamellar } \\
\text { system, multivesicular bodies originate from } \\
\text { chloroplasts, chloroplasts clustered around a } \\
\text { group of multivesicular bodies }\end{array}$ & Gomphrena globosa & Virus particle & Appiano et al., 1978 \\
\hline & $\begin{array}{l}\text { Large inter-membranous sac, rearrangement } \\
\text { of the thylakoids }\end{array}$ & Datura stramonium & - & Bassi et al., 1985 \\
\hline \multicolumn{5}{|l|}{ Unassigned/Tombusviridae } \\
\hline $\begin{array}{l}\text { Maize necrotic streak virus } \\
\text { (MNeSV) }\end{array}$ & $\begin{array}{l}\text { Chloroplast swollen, out membrane } \\
\text { invagination }\end{array}$ & Zea mays & - & De Stradis et al., 2005 \\
\hline \multicolumn{5}{|l|}{ Tymovirus/Tymoviridae } \\
\hline $\begin{array}{l}\text { Melon rugose mosaic virus } \\
\text { (MRMV) }\end{array}$ & Peripheral vesicles, tendency to aggregate & Cucumis melo & - & Mahgoub et al., 1997 \\
\hline $\begin{array}{l}\text { Turnip yellow mosaic virus } \\
\text { (TYMV) }\end{array}$ & $\begin{array}{l}\text { Peripheral vesicles, reduction of grana } \\
\text { number, chlorophyll content; increases in } \\
\text { amounts of phytoferritin and numbers of } \\
\text { osmiophilic globules }\end{array}$ & Brassica rapa & Viron, Viral RNA & $\begin{array}{l}\text { Ushiyama and Matthews, } \\
\text { 1970; Hatta and } \\
\text { Matthews, } 1974\end{array}$ \\
\hline $\begin{array}{l}\text { Belladonna mottle virus physalis } \\
\text { mottle strain (BeMV-PMV) }\end{array}$ & $\begin{array}{l}\text { Vesicles develop in chloroplasts, } \\
\text { vesiculations of the outer membranes }\end{array}$ & Datura stramonium & Viron & Moline, 1973 \\
\hline $\begin{array}{l}\text { Wild cucumber mosaic virus } \\
\text { (WCMV) }\end{array}$ & $\begin{array}{l}\text { Double membrane vesicles in chloroplasts, } \\
\text { single membrane vesicles surrounding } \\
\text { chloroplasts }\end{array}$ & Marah oreganus & Virus particle & Allen, 1972 \\
\hline \multicolumn{5}{|l|}{ Hordeivirus/Virgaviridae } \\
\hline \multirow[t]{2}{*}{$\begin{array}{l}\text { Barley stripe mosaic virus } \\
\text { (BSMV) }\end{array}$} & $\begin{array}{l}\text { Surrounded chloroplasts, cytoplasmic } \\
\text { invaginations into chloroplasts, aggregated } \\
\text { chloroplasts, rearrangement of the thylakoids, } \\
\text { electron transparent vacuoles in stroma }\end{array}$ & Hordeum vulgare & Viron & $\begin{array}{l}\text { Carroll, 1970; } \\
\text { Zarzyńska-Nowak et al., } \\
2015\end{array}$ \\
\hline & $\begin{array}{l}\text { Peripheral vesicles; Type1: elongated grana } \\
\text { or anastomosed lamellae, composed of } \\
\text { pellucid stroma, twisted or convoluted } \\
\text { membranes forming tubular networks; Type2: } \\
\text { swollen and contained disarranged internal } \\
\text { membranes; Type3: electron dense stroma, } \\
\text { cytoplasmic invaginations. }\end{array}$ & Datura stramonium & Genomic ssRNA & McMullen et al., 1978 \\
\hline
\end{tabular}


TABLE 2 | Continued

\begin{tabular}{|c|c|c|c|c|}
\hline Plant Virus ${ }^{\star}$ & Chloroplast Abnormality & Plant Host & Virus Factor & References \\
\hline & $\begin{array}{l}\text { Rounded and clustered chloroplasts, } \\
\text { cytoplasmic invaginations and inclusions at } \\
\text { the periphery }\end{array}$ & $\begin{array}{l}\text { Nicotiana } \\
\text { benthamiana }\end{array}$ & $\begin{array}{l}\text { TGB2, } \mathrm{CP}, \gamma \mathrm{b} \\
\text { virus-like particle }\end{array}$ & Torrance et al., 2006 \\
\hline \multicolumn{5}{|l|}{ Pomovirus/Virgaviridae } \\
\hline Potato mop-top virus (PMTV) & $\begin{array}{l}\text { Large starch grains, large cytoplasmic } \\
\text { inclusion, terminal extension, }\end{array}$ & Nicotianabenthamiana & $\begin{array}{l}\text { Genomic RNA, } \\
\text { CP, TGB2 }\end{array}$ & Cowan et al., 2012 \\
\hline \multicolumn{5}{|l|}{ Tobamovirus/Virgaviridae } \\
\hline Ribgrass mosaic virus (RMV) & $\begin{array}{l}\text { Disappearance of stroma, decrease in grana } \\
\text { lamella, Large starch grains, osmiophilic } \\
\text { granules }\end{array}$ & Nicotiana tabacum & - & Xu and Feng, 1998 \\
\hline \multirow[t]{4}{*}{ Tobacco mosaic virus (TMV) } & Aggregates and vecuoles in chloroplast & $\begin{array}{l}\text { Lycopersicon } \\
\text { esculentum }\end{array}$ & & Shalla, 1964 \\
\hline & $\begin{array}{l}\text { Enlarged plastids, supergranal thylakoids, } \\
\text { large accumulations of osmiophilic bodies }\end{array}$ & $\begin{array}{l}\text { Lycopersicon } \\
\text { esculentum }\end{array}$ & - & Arnott et al., 1969 \\
\hline & $\begin{array}{l}\text { Disappearance of stroma, decrease in grana } \\
\text { lamella, large starch grains, osmiophilic } \\
\text { granules }\end{array}$ & Nicotiana tabacum & $\mathrm{CP}$ & Xu and Feng, 1998 \\
\hline & $\begin{array}{l}\text { Swelling, more osmophilic plastoglobuli, } \\
\text { loosened thylakoid structure }\end{array}$ & Capsicuum anuum & - & Mel'nichuk et al., 2002 \\
\hline TMV U5 strain & Peripheral vesicles & Nicotiana tabacum & Virus particle & Betto et al., 1972 \\
\hline TMV yellow strain & $\begin{array}{l}\text { Filled with osmiophilic globules, rearranged, } \\
\text { swollen or eliminated lamellar system, } \\
\text { extensive chloroplast degradation }\end{array}$ & Solanum tuberosum & - & Liu and Boyle, 1972 \\
\hline TMV flavum strain (TMV-Flavum) & $\begin{array}{l}\text { Swollen or globular chloroplast, distorted } \\
\text { thylakoid membranes, grana depletion, } \\
\text { unidentified granular matter }\end{array}$ & Nicotiana tabacum & MP, CP & Lehto et al., 2003 \\
\hline Tomato mosaic Virus (ToMV) & $\begin{array}{l}\text { Slightly swollen and distorted cholroplast, } \\
\text { large starch grains }\end{array}$ & Nicotiana tabacum & Virus particle & Ohnishi et al., 2009 \\
\hline ToMV $L_{11} Y$ strain (ToMV- $\left.L_{11} Y\right)$ & $\begin{array}{l}\text { Flaccid chloroplast, reduced thylakoid stacks } \\
\text { and enlarged spaces between the stacks, } \\
\text { cytoplasm penetrates into chloroplast, } \\
\text { tubular complexes }\end{array}$ & Nicotiana tabacum & - & Ohnishi et al., 2009 \\
\hline
\end{tabular}

SSRNA NEGATIVE STRAND VIRUSES

\section{Tospovirus/Bunyaviridae}

Tomato spotted wilt virus (TSWV)

Tenuivirus/Unassigned

Rice stripe virus (RSV)
Peripheral vesicles

Reduced sheets of grana stacks, increased amount and size of starch granules

Membrane proliferations
Nicotiana tabacum

Oryza Sativa

Nicotiana benthamiana
Mohamed, 1973

Zhao et al., 2016

\section{SSDNA VIRUSES}

\section{Begomovirus/Geminiviridae}

Abutilon Mosaic Virus (AbMV)
Disorganization of thylakoid system, grana-stroma elimination

Degenerated thylakoids, more plastoglobuli, less starch, and accumulation of amorphous electron-dense material

Generation of stromules

$\begin{array}{lll}\begin{array}{l}\text { Abutilon spec } \\ \text { Abutilon selovianum }\end{array} & \text { Genomic DNA } & \begin{array}{l}\text { Schuchalter-Eicke and } \\ \text { Jeske, } 1983\end{array} \\ & \text { Gröning et al., } 1987 \\ \begin{array}{l}\text { Nicotiana } \\ \text { benthamiana }\end{array} & \text { MP } & \text { Krenz et al., } 2012\end{array}$

*Virus taxonomy is in format of Genus/Family. - Not addressed. ssRNA, single-stranded RNA; ssDNA, single-stranded DNA.

chloroplasts by interfering with the synthesis and transport of CPRPs (Lindbeck et al., 1991, 1992; Ohnishi et al., 2009).

Besides CPs, other viral components are also able to cause chloroplast malformation and contribute to symptom. For example, transgenic expression of CaMV transactivator/viroplasmin (Tav) protein in tobacco plants results in a virus-like chlorosis symptom associated with the abnormal thylakoid stacks (Figure 1, Table 2) and reduces expression of CPRGs (Waliullah et al., 2014). The potexvirus AltMV TGB3, different from its counterpart 


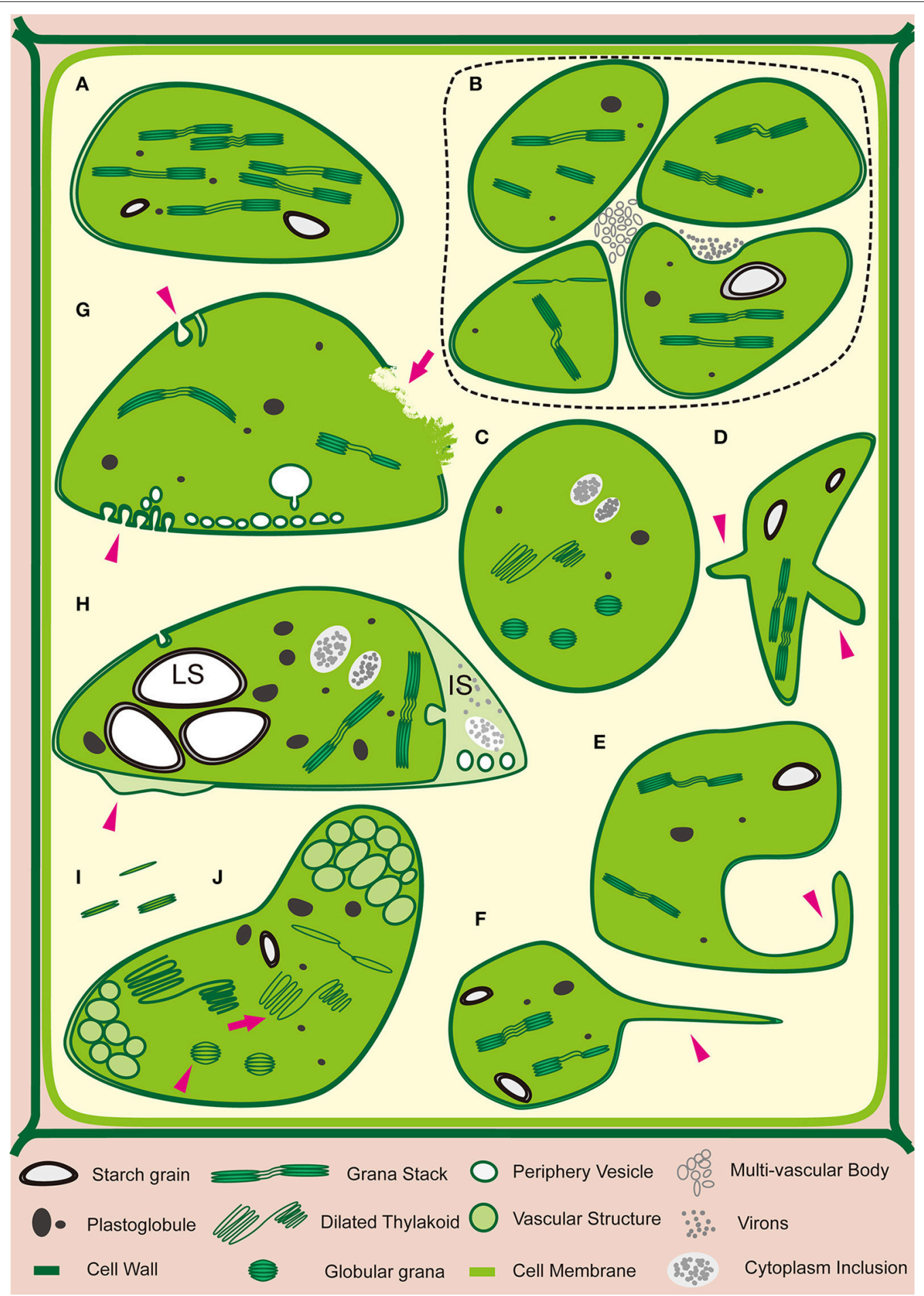

FIGURE 1 | Changes in the Ultrastructure of Chloroplasts Induced by Virus Infection. (A) Normal chloroplast. (B) Aggregated chloroplasts (surrounded with dotted line). (C) Swollen chloroplast. (D) Chloroplast with membrane-bound extrusions. Arrow heads indicate membrane extrusions. (E) Amoeboid-shaped chloroplast, arrow head indicates chloroplast membrane extrusions. (F) Chloroplast with stromule, arrow head indicates the stromule. (G) Chloroplast with irregular out-membrane structures such as peripheral vesicle, cytoplasmic invagination, membrane proliferations and broken envelope. Arrow heads indicates cytoplasmic invaginations, arrow indicates broken envelope of chloroplast. (H) Chloroplast with abnormal content changes such as small vesicles, membrane proliferations (arrow head) and inter-membranous sac (IS), large starch grain (LS) and exaggeration of plastoglobules. (I) Disorganized grana scattering into the cytoplasm. (J) Chloroplast with unusual photosynthetic structures such as dilated thylakoid (arrow) and globular grana (arrow head) and vascular structures. 
PVX TGB3, has a chloroplast-targeting signal and preferentially accumulates around the chloroplast membrane (Lim et al., 2010). Overexpression of AltMV TGB3 causes vesiculation at the chloroplast membrane (Figure 1, Table 2) and veinal necrosis symptom (Lim et al., 2010; Jang et al., 2013). AltMV TGB3 strongly interacts with PS II oxygenevolving complex protein PsbO and this interaction is believed to have a crucial role in viral symptom development and chloroplast disruption (Jang et al., 2013). In PVY-infected cells, viral multifunctional protein HC-Pro may contribute to the change in the number and size of chloroplast by interfering with the normal activity of the chloroplast division-related factor MinD through direct protein interaction (Jin et al., 2007, Table 1). The tenuivirus RSV NSvc4 protein functions as an intercellular movement protein and is localized to PD as well as chloroplast in infected cells. Over-expression of NSvc4 exacerbated malformations of chloroplast (Figure 1, Table 2) and disease symptoms. Interestingly, the chloroplast localization of NSvc4 is dispensable for the symptom determination while the NSvc4 transmembrane domain probably affects the chloroplast from outside ( $\mathrm{Xu}$ and Zhou, 2012).

\section{Effect of Virus Infection on Expression of Chloroplast-Targeted Proteins}

Studies on the effect of virus infection on expression of chloroplast proteins at the transcriptomic and proteomic levels provide insights into the molecular events during symptom expression. In the susceptible plant response to virus infection, the majority of significantly changed proteins are identified to be located in chloroplasts or associated with chloroplast membranes. Most of them are down-regulated and correlate with the severity of chlorosis (Dardick, 2007; Shimizu et al., 2007; Lu et al., 2012; Rodríguez et al., 2012; Kundu et al., 2013; Wu et al., 2013; Mochizuki et al., 2014a). During virus infection, CPRPs represent the most common viral targets. Among them, the light harvesting antenna complex (Naidu et al., 1984a,b, 1986; Liu et al., 2014) and the oxygen evolving complex (OEC) (Takahashi et al., 1991; Takahashi and Ehara, 1992; Pérez-Bueno et al., 2004; Sui et al., 2006; Wang et al., 2015) of PS II are in thylakoid, while RbCS and RubisCO activase (RCA, an AAA-ATPase family protein) are in chloroplast stroma (Díaz-Vivancos et al., 2008; Pineda et al., 2010; Moshe et al., 2012; Kundu et al., 2013).

As the biosynthesis of CPRPs is a complicated process with a series of steps (Seidler, 1996), plant virus can affect CPRPs at varied levels including transcription, post-transcription, translation, transportation into the chloroplast, assembly and degradation in chloroplast, to contribute to symptom development (Lehto et al., 2003; Pérez-Bueno et al., 2004).

Several plant viruses perturb CPRPs expression at transcription level either in chloroplast or via retrograde signaling into nucleus. Infection of TMV flavum strain leads to a total depletion of PS II core complex and OEC, including chloroplast-encoded CPRP PsbA and nuclear-encoded CPRPs LhcB1, LhcB2 (light-harvesting chlorophyll a/b-binding protein $\mathrm{B} 1, \mathrm{~B} 2)$ and PsbO. However, the PsbA mRNA accumulated to a higher level in the infected leaves (Lehto et al., 2003). Thus,
TMV flavum may block PsbA translation via reducing the level of chloroplast ribosomal RNA (Fraser, 1969) and inhibit the transcription of nuclear-encoded CPRGs through feed-back signaling (Lehto et al., 2003). Similarly, in the case of CMV pepo strain and its $\mathrm{CP}_{129}$ mutant isolates, the down-regulation patterns of transcription levels of different CPRGs correlated with the amino acid substitution in the CP protein of the relative isolates, where CMV CP probably repress the transcription of CPRGs via the retrograde signaling from chloroplast into nucleus (Mochizuki et al., 2014a).

It is interesting that plant virus can also exploit host RNA silencing machinery to manipulate CPRGs at post-transcription level. The enlightening evidence is illustrated by CMV-Y satellite (CMV-Y-sat) RNA which can disturb chloroplast function and induce disease symptoms (Shimura et al., 2011; Smith et al., 2011). A 22-nt siRNA derived from CMV-Y-sat RNA targets the magnesium protoporphyrin chelatase subunit I (ChlI) gene transcripts and down-regulates its expression by RNA silencing (Table 1), which leads to a more sever symptom characterized as bright yellow mosaic (Takanami, 1981; Shimura et al., 2011; Smith et al., 2011). In addition, infection by viroids (small nonprotein-coding RNAs) results in the production of viroid-derived small RNAs (vd-sRNAs) (Papaefthimiou et al., 2001; Martínez de Alba et al., 2002). Peach latent mosaic viroid (PLMVd) belongs to family Avsunviroidae whose members replicate in chloroplast, and may elicit an albino-variegated phenotype (peach calico, PC) with blocked chloroplast development and depletion of chloroplast-encoded proteins (Rodio et al., 2007). The PLMVd variants associated with PC contain an insertion of 12-14 nt that folds into a hairpin with a U-rich tetraloop, the sequence of which is critical for inciting the albino phenotype.. Actually, vd-sRNAs from the hairpin insertion induce cleavage of the mRNA encoding the CPRP chloroplastic heat-shock protein 90 (cHSP90) as predicted by RNA silencing, eventually resulting in PC symptoms (Navarro et al., 2012).

In addition to the virus-derived small RNAs, plant viruses may also modify host microRNA (miRNA) pathway for targeting CPRGs transcripts. The tenuivirus RSV, causing a devastating disease in East Asia countries, hijacks CPRP during infection and perturbs photosynthesis (Satoh et al., 2010; Shi et al., 2016). The perturbation of photosynthesis by RSV is probably caused by up-regulating a special miRNA that targets key genes in chloroplast zeaxanthin cycle, which impairs chloroplast structure and function (Yang et al., 2016).

Viral factors may reduce the level of CPRPs by direct association with target proteins. Tobamoviruses CPs particularly associate with the PS II complex and reduce the levels of PsbP and PsbQ (Hodgson et al., 1989; Pérez-Bueno et al., 2004; Sui et al., 2006). PVY HC-Pro can reduce the amount of ATP synthase complex by interaction with the NtCF1 $\beta$-subunit in both the PVY-infected (Table 1) and the HC-Pro transgenic tobacco plants, leading to a decreased photosynthetic rate ( $\mathrm{Tu}$ et al., 2015). Potyviruses TuMV, SMV, SYSV, and OYDV may hijack $\mathrm{RbCS}$ and/or RbCL via the interaction with $\mathrm{P} 3$ or P3N-PIPO during infection to perturb photosynthetic activity (Lin et al., 2011). Potyvirus SCMV infection significantly down-regulates mRNA level of photosynthetic Fd V rather than that of the other 
isoproteins (Fd I and Fd II) in maize, while SCMV HC-Pro specifically interacts with the chloroplast precursor of Fd V via TP in cytoplasm outside the chloroplasts (Table 1), suggesting that SCMV HC-Pro perturbs the importing of Fd V into chloroplasts and leads to structure and function disturbance of chloroplast (Cheng et al., 2008). Potyvirus SMV P1 (a serine protease) strongly interacts with host plant-derived, but only weakly with non-host Arabidopsis-derived, Rieske Fe/S protein of cytochrome b6/f complex, an indispensable component of the photosynthetic electron transport chain in chloroplasts (Table 1), suggesting that SMV P1-Rieske Fe/S protein interaction is involved in symptom development (Shi et al., 2007). RSV disease specific protein (SP) is a symptom determinant protein and its overexpression enhances RSV symptom (Kong et al., 2014). During RSV infection, accumulation of SP is associated with alteration in structure and function of chloroplast. SP interacts with 23-kD OEC PsbP, and relocates PsbP from chloroplast into cytoplasm (Table 1), while silencing of $P s b P$ enhances disease symptom severity and virus accumulation (Kong et al., 2014).

\section{CHLOROPLAST IS INVOLVED IN THE PROCESS OF THE PLANT VIRUS LIFE CYCLE}

Increasing studies have unraveled that chloroplast constituents participate in different stages during virus infection. For example, chloroplast is reported to be associated with viral uncoating, an important step of replication (Xiang et al., 2006). Tombusvirus CNV CP harbors an arm region of 38 amino acids that functions as a chloroplast TP to direct CP import to the chloroplast stroma, which is critical for viral disassembly. CNV CP mutant deficient in exposure of the arm region is inefficient to establish infection, highlighting the crucial role of chloroplast targeting in $\mathrm{CNV}$ uncoating (Xiang et al., 2006).

\section{Chloroplast and Its Factors Participate in Virus Replication}

Chloroplast affords compartment and membrane contents for the replication of plant viruses and probably helps them to evade the RNA-mediated defense response (Ahlquist et al., 2003; Dreher, 2004; Torrance et al., 2006). Plant viruses propagate via RNA-protein complex named viral replication complexes (VRCs), which are the factory for producing progeny viruses (Más and Beachy, 1998, 2000; Asurmendi et al., 2004). During replication of RNA viruses, double-strand RNA (dsRNA) is generated as an intermediate product. As a response against virus infection, the dsRNA replication intermediates can be detected by the host RNA silencing machinery (Angell and Baulcombe, 1997; Baulcombe, 1999). Correspondingly, plant viruses have evolved some mechanisms by encoding viral suppressor of RNA silencing or by associating replication with host membranes (Ahlquist, 2002; Ahlquist et al., 2003). For a large group of viruses, VRCs are associated with the chloroplast envelope, particularly the peripheral vesicles and cytoplasmic invaginations in chloroplast (Figure 1, Table 2), including alfamovirus AMV (de Graaff et al., 1993), hordeivirus BSMV (Carroll, 1970;
Torrance et al., 2006), potyviruses MDMV (Mayhew and Ford, 1974), PPV (Martin et al., 1995), TEV (Gadh and Hari, 1986), TuMV (Kitajima and Costa, 1973), and tymovirus TYMV (Lafleche et al., 1972; Bové and Bové, 1985; Garnier et al., 1986; Lesemann, 1991; Dreher, 2004). The chloroplast membrane associated organization probably helps to shield viral RNAs from recognition by host RNA silencing machinery (Dreher, 2004).

Viral factors, either viral genomic RNAs or proteins, can mediate the chloroplast targeting of VRCs for replication and subsequent virion assembly (Prod'homme et al., 2003; Jakubiec et al., 2004; Torrance et al., 2006). BSMV replicative dsRNA intermediates exist in the chloroplast peripheral vesicles during infection (McMullen et al., 1978; Lin and Langenberg, 1984, 1985; Torrance et al., 2006); in the presence of the viral genome RNA, both TGB2 and $\gamma \mathrm{b}$ can be recruited to chloroplasts for virus replication (Torrance et al., 2006). The low $\mathrm{pH}$ condition of chloroplast vesicles where TYMV RNA is synthesized is required for the interaction between viral RNA and CP to process virion assembly (Rohozinski and Hancock, 1996). The TYMV VRC-associated membrane vesicles localize at the chloroplast envelope (Prod'homme et al., 2001). TYMV $\mathrm{N}$-terminal replication protein $(140 \mathrm{~K})$ is a key organizer of TYMV VRCs assembly and a major determinant for chloroplast localization of TYMV for replication. The $140 \mathrm{~K}$ protein can localize to the chloroplast envelope autonomously and interacts with the C-terminal replication protein $(66 \mathrm{~K})$ to mediate the targeting of $66 \mathrm{~K}$ to the chloroplast envelope (Prod'homme et al., 2003; Jakubiec et al., 2004). TuMV $6 \mathrm{~K}$ protein $(6 \mathrm{~K}$ or $6 \mathrm{~K} 2$ ) can autonomously allocate to chloroplast membrane and promote the adhesion of the adjacent chloroplasts via actomyosin motility system in infected host cells. During the infection, TuMV $6 \mathrm{~K}$ induces the formation of $6 \mathrm{~K}$-containing membranous vesicles at endoplasmic reticulum exit sites and sequentially traffic to chloroplast, while the chloroplast-bounded $6 \mathrm{~K}$-vesicles are recruited to VRCs containing viral dsRNA (Wei et al., 2010), supporting the idea that the chloroplast-bound 6 K vesicles are the cellular compartment for TuMV replication. Blocking the fusion of virus-induced vesicles with chloroplasts by the inhibition of SNARE protein Syp71 significantly reduced the viral infection (Wei et al., 2013).

Special chloroplast components are involved in the targeting of VRCs to chloroplast. The lipid in chloroplast membrane can associate with pomovirus PMTV TGB2 (Table 1) and facilitate the viral RNA to localize to chloroplast membranes for replication (Cowan et al., 2012). Furthermore, chloroplast factors also participate in the formation of VRCs. Proteomic analysis suggests that sobemovirus RYMV recruits CPRPs such as Ferredoxin-NADP reductase (FNR), RbCS, RCA, and chaperonin 60 to its VRCs during all the infectious stages including replication, long-distance trafficking and symptoms development (Brizard et al., 2006). The $43 \mathrm{kD}$ CPRP chloroplast phosphoglycerate kinase (cPGK) specifically interacts with $3^{\prime}$ UTR of the potexvirus BaMV genomic RNA (Lin et al., 2007, Table 1). Silencing of $N b-c P G K$ or mislocalization of $c P G K$ protein reduced $\mathrm{BaMV}$ accumulation, suggesting that $\mathrm{CPGK}$ may mediate BaMV RNA targeting to chloroplast for replication (Cheng et al., 2013). Interestingly, in Arabidopsis genotype Cvi-0 
the natural recessive resistance gene $r w m 1$ against potyvirus WMV encodes a mutated version of cPGK (Ouibrahim et al., 2014), illuminating that the conserved CPRP cPGK may be required for successful replication and infection of a range of plant viruses (Lin et al., 2007; Ouibrahim et al., 2014).

\section{Chloroplast Factors Participate in Viral Movement}

The intercellular trafficking and systemic spreading of plant virus need movement proteins (MPs) to fulfill the transport via symplastic routes within plant hosts (Wolf et al., 1989; Ding et al., 1992; Imlau et al., 1999; Lazarowitz and Beachy, 1999). To facilitate virus movement, varied MPs possess common features such as nucleic acid binding activity (Citovsky et al., 1990), specific plasmodesmata (PD) localization (Ding et al., 1992; Fujiwara et al., 1993) and the ability to increase the size exclusion limit of PD (Wolf et al., 1989).

Chloroplast and its factors also participate in virus movement. AltMV TGB3 has a chloroplast-targeted signal and accumulates preferentially in mesophyll cells, which is essential for virus movement. Mutation of the chloroplast-targeted signal in AltMV TGB3 impairs virus movement from epidermal into the mesophyll cells as well as viral long-distance traffic (Lim et al., 2010). Geminivirus AbMV MP interacts with chloroplasttargeted $70-\mathrm{kD}$ heat shock protein (cpHSC70-1) and colocalized to chloroplasts (Table 1). Silencing of $c$ PHSC70-1 affects chloroplast stability and causes a substantial reduction of AbMV movement but has no effect on viral DNA accumulation (Krenz et al., 2010, 2012). AbMV can replicate in chloroplast (Gröning et al., 1987, 1990) and induce the biogenesis of stromule network (Figure 1, Table 2). AbMV may use cpHSC70-1 for trafficking along chloroplast stromules into a neighboring cell or from plastids into the nucleus (Krenz et al., 2012).

Viral factors can interact with and hijack chloroplast factors from their normal function and to help viral movement. The CaMV multifunctional P6 protein is the most abundant present in VRCs (Hohn et al., 1997) and associates with PD (Rodriguez et al., 2014). Interestingly, CaMV P6 also interacts with the chloroplast unusual positioning protein1 (CHUP1) (Table 1) that is a thylakoid membrane-associated protein for mediating the routine movement of chloroplast on microfilaments in response to light intensity (Oikawa et al., 2003, 2008). Silencing of CHUP1 slows the formation rate of CaMV local lesion (Angel et al., 2013). Thus, the CaMV P6 protein may mediate the intracellular movement of VRCs to the PD by binding to CHUP1 (Angel et al., 2013). Tobamoviruses ToMV and TMV MPs bind RbCS (Table 1) and the interaction occurs at PD (Zhao et al., 2013). Silencing of $R b C S$ reduced intercellular movement and systemic trafficking of TMV and ToMV (Zhao et al., 2013). Thus, it may be a common strategy for tobamoviruses to hijack RbCS for efficient movement. In addition to MPs, tobamoviruses need their CPs for efficient long distance movement (Wisniewski et al., 1990; Reimann-Philipp and Beachy, 1993; Ryabov et al., 1999). ToMV CP-interacting protein-L (IP-L) is a chloroplast protein (Table 1) and is positively induced by ToMV infection (Zhang et al., 2008). Depletion of $I P-L$ delayed ToMV systemic movement and symptoms (Li et al., 2005). Dianthovirus RCNMV MP interacts with chloroplast protein glyceraldehyde 3-phosphate dehydrogenase subunit A (GAPDH-A) (Table 1), while silencing of $G A P D H-A$ inhibits viral MP localization to the cortical VRCs and reduces RCNMV multiplication in the inoculated leaves (Kaido et al., 2014). Therefore, GAPDH-A is relocated from chloroplast to cortical VRCs to facilitate viral cell-to-cell movement during RCNMV infection.

Based on the current studies, it is clear that plant viruses have evolved to utilize abundant chloroplast proteins to regulate their movement.

\section{CHLOROPLASTS AFFECT PLANT DEFENSE AGAINST VIRUSES}

Several hormones regulate plant defense to viruses (Alazem and Lin, 2015). Two of them are salicylic acid (SA) and jasmonic acid (JA). Chloroplast is the crucial site for the biosynthesis of SA (Boatwright and Pajerowska-Mukhtar, 2013; Seyfferth and Tsuda, 2014) and JA (Wasternack, 2007; Schaller and Stintzi, 2009; Wasternack and Hause, 2013). Moreover, chloroplast factors are also involved in the regulation of antagonistic interactions of SAJA synthesis and signaling (Kunkel and Brooks, 2002; Xiao et al., 2012; Zheng et al., 2012; Lemos et al., 2016). The chloroplastrelated regulation of SA and JA biosynthesis is schemed in Figure 2.

SA is a small phenolic compound that plays central roles in plant defense against biotrophic pathogens and is essential for the establishment of local and systemic acquired resistance. The majority of pathogen-induced SA is synthesized via the isochorismate pathway in chloroplasts (Boatwright and Pajerowska-Mukhtar, 2013; Seyfferth and Tsuda, 2014). As a key activator of plant defense response, SA biosynthesis and signaling are activated during incompatible plant-virus interaction (Wildermuth et al., 2001; Garcion et al., 2008). Disruption of SA pathway compromises plant resistance against viruses (Alazem and Lin, 2015). In contrast, the application of SA or its analogs often delays the onset of viral infection and disease establishment by improving plant basal immunity (Radwan et al., 2006, 2007, 2008; Falcioni et al., 2014). A chloroplast-localized protein, named calcium-sensing receptor, is found to act upstream of SA accumulation to link chloroplasts to cytoplasmic-nuclear immune responses (Nomura et al., 2012).

JA is an oxylipin, or oxygenated fatty acid and is synthesized from linolenic acid by the octadecanoid pathway, whose biosynthesis starts with the conversion of linolenic acid to 12oxo-phytodienoic acid (OPDA) in the chloroplast membranes (Turner et al., 2002). JA is thought to play a positive defense role in compatible plant-virus interactions (Alazem and Lin, 2015). For example, silencing of Coronatine insensitive 1 (COI1), a gene involved in the JA signaling pathway, accelerates the development of symptoms caused by co-infection of PVX and PVY, and accumulation of viral titers at early stages of infection (García-Marcos et al., 2013).

The chloroplasts are major sites of the production of reactive oxygen species (ROS), and the photosynthetic electron 


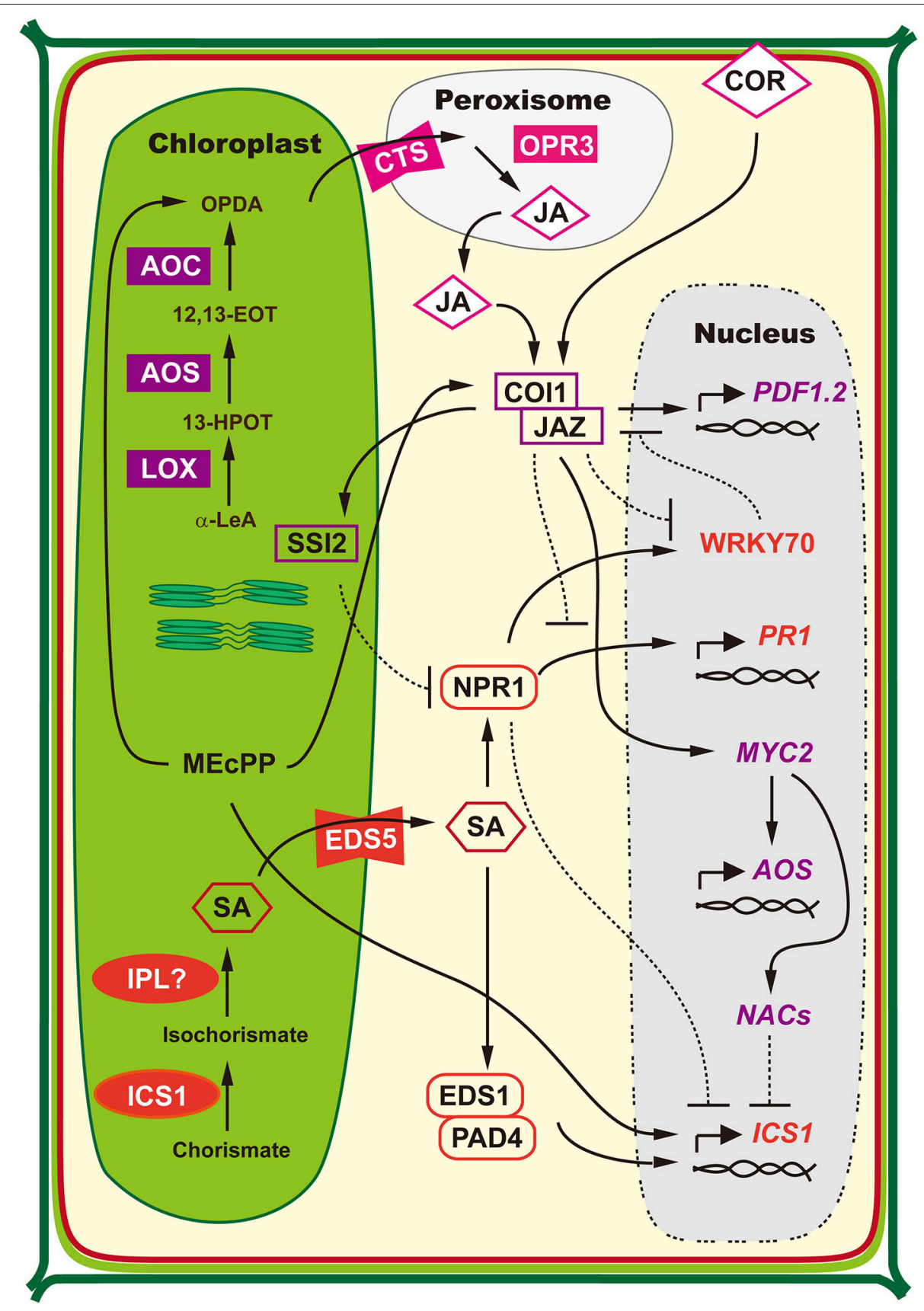

FIGURE 2 | Regulation of SA and JA Biosynthesis is Associated with Chloroplast. SA biosynthesis is predominantly accomplished by nucleus-encoded chloroplast-located isochorismate synthase (ICS1). In chloroplasts, ICS catalyzes the conversion of chorismate into isochorismate, which is further converted to SA by undetermined isochorismate pyruvate lyase (IPL). The MATE-transporter ENHANCED DISEASE SUSCEPTIBILITY 5 (EDS5) is responsible for SA transportation from chloroplast into cytosol. Defense-elicited ENHANCED DISEASE SUSCEPTIBILITY 1 (EDS1) and PHYTOALEXIN DEFICIENT 4 (PAD4) complex works in a positive feedback loop to control SA synthesis, which is regulated by SA. While in a negative feedback loop, accumulation of ICS1-produced SA results in the deoligomerization of NON-EXPRESSOR OF PATHOGENESIS-RELATED GENES 1 (NPR1), which is then translocated into nucleus where it suppresses the ICS1 expression (modified from Boatwright and Pajerowska-Mukhtar, 2013; Seyfferth and Tsuda, 2014). JA biosynthesis originates from polyunsaturated fatty acids released from chloroplast membranes. Firstly, $\alpha$-linolenic acid (18:3) ( $\alpha$-LeA) is catalyzed by lipoxygenase (LOX) to yield the 13-hydroperoxy derivative 13(S)-hydroperoxy-octadecatrienoic acid (13-HPOT). The dehydration of 13-HPOT by allene oxide synthase (AOS) results in the formation of unstable 12, 13(S)-epoxy-octadecatrienoic acid (12,13-EOT), which is the committed step of JA biosynthesis. Then the 12,13-EOT is converted to 12-oxophytodienoic acid (OPDA) by allene oxide cyclase (AOC) through cyclization and concludes the chloroplast-localized part of JA biosynthesis. Subsequently, OPDA is released from chloroplasts and taken up into peroxisomes by transporter COMATOSE (CTS3). The remaining steps are located in peroxisomes and JA is generated through reduction of the cyclopentenone by OPDA reductase 3 (OPR3) and subsequent three cycles of $\beta$-oxidation for side-chain shortening. The JA co-receptor complex of 


\section{FIGURE 2 | Continued}

CORONATINE INSENSITIVE1 (COI1) and the negative regulator JAZMONATE ZIM DOMAIN (JAZ) proteins regulates the positive feedback loop of JA biosynthesis. Formation of JA subjects JAZ to proteasomal degradation, which allows MYC2 to activate the JA biosynthesis genes such as AOS, AOC, and LOX (modified from Wasternack, 2007; Schaller and Stintzi, 2009; Wasternack and Hause, 2013). NPR1 is the central transcriptional regulator of SA-mediated defense responses and directly regulates PATHOGENESIS-RELATED 1 (PR1) expression (Wang et al., 2006). By wounding or JA treatment, COI1-JAZ co-receptor promotes the degradation of JAZ and release the positively acting transcription factors that binds to JA-responsive promoters to initiate the transcription of JA-responsive genes, such as PLANT DEFENSIN1.2 (PDF1.2) (Chini et al., 2007; Thines et al., 2007; Yan et al., 2009). During the antagonistic interplay between SA and JA, NPR1 suppresses COl1-JAZ mediated induction of JA-responsive genes via WRKY transcription factors, while JA also represses WRKY in COl1-dependent pathway (Li et al., 2004; Gao et al., 2011). On the other hand, the JA signaling proteins, such as chloroplast factor SUPPRESSOR OF SA INSENSITIVITY 2 (SSI2), negatively regulate SA-mediated NPR1-dependent defense responses (Kunkel and Brooks, 2002). Further, the phytotoxin coronatine (COR), a molecular mimic of JA, activates NAC transcription factors via COI1-JAZ and MYC2, which eventually inhibits SA accumulation through repressing ICS1 expression (Zheng et al., 2012). In addition, the stress-induced methylerythritol cyclodiphosphate (MEcPP) acts as a plastid-to-nucleus retrograde signal to increase the transcription level of ICS1 (Xiao et al., 2012). Meanwhile, MECPP increase the level of JA precursor OPDA and induce JA-responsive genes via a COl1-dependent manner in the presence of high SA (Lemos et al., 2016). Solid lines with arrow head represent activation or promotion, dotted lines with bar head to represent deactivation or inhibition.

transport chain is responsible for ROS generation (Asada, 2006; Muhlenbock et al., 2008). Superoxide anion $\left(\mathrm{O}_{2}^{-}\right)$is the primary reduced product of $\mathrm{O}_{2}$ photoreduction and its disproportionation produces $\mathrm{H}_{2} \mathrm{O}_{2}$ in chloroplast thylakoids (Asada, 2006; Muhlenbock et al., 2008). The burst of intracellular ROS can be detected during virus infection in both incompatible and compatible interactions (Allan et al., 2001; Hakmaoui et al., 2012). Chloroplast-sourced ROS are essential for hypersensitive response (HR) induced by incompatible defensive response (Torres et al., 2006; Zurbriggen et al., 2010).

The stromules could function to facilitate the magnification and transport of defensive signals into the nucleus. Interestingly, the stromules can be induced during $N$-mediated TMV resistance response. Further, a number of stromules surround nuclei during plant defense response, which is correlated with the accumulation of chloroplast-localized defense protein NRIP1 and $\mathrm{H}_{2} \mathrm{O}_{2}$ in the nucleus. In the absence of virus infection, suppression of chloroplast CHUP1 induces stromules and enhances programmed cell death constitutively (Caplan et al., 2015; Gu and Dong, 2015). In addition, the ultrastructural changes in chloroplast can also be a part of resistant response. For examples, during the hypersensitive reaction of $N$-mediated TMV resistance, the chloroplasts swelled and the membrane burst before tonoplast ruptured (da Graça and Martin, 1975). During the course of lesion development caused by the nepovirus TRSV, the changes in chloroplast ultrastructure (rounding of chloroplasts) enlighten that chloroplast disturbance could reflect plant-virus incompatible responses (White and Sehgal, 1993). The ultrastructure aberrations of chloroplast represent the intensity of apoptotic processes in PVY ${ }^{\mathrm{NTN}}$ infection (PompeNovak et al., 2001). Thus, the malformation of chloroplast may also indicate a defense response in compatible host-virus interaction.

Removal of the lower epidermis from cowpea and tobacco leaves inoculated with TMV or TNV resulted in reduction of local lesion numbers, indicating that the chloroplast-free epidermal cells possess an active role in virus infection (Wieringabrants, 1981). Further, chloroplast may also have a role in host defense against virus during the compatible plant-virus interaction. Previous studies found that light could influence host susceptibility to virus infection. Despite there is a report that a short burst of light after dark treatment enhances plant susceptibility to TMV infection (Helms and McIntyre, 1967), in most cases, low light and dark treatment is beneficial for viruses to establish infection and increase host's susceptibility compared to light treatment (Bawden and Roberts, 1947; Matthews, 1953; Wiltshire, 1956; Helms, 1965; Helms and McIntyre, 1967; Cheo, 1971; Manfre et al., 2011). The negative correlation between light and infectivity suggest that the robust photosynthesis and chloroplast function play a positive role in defense response during plant-virus interactions.

In compatible plant-virus interactions, some chloroplast factors are sequestrated by virus to block antiviral defense and fuel virus infection. For examples, AMV CP is essential for virus replication and encapsidation, and interacts with the chloroplast protein PsbP in the cytosol (Table 1), while mutations that prevent the dimerization of $\mathrm{CP}$ abolish this interaction (Balasubramaniam et al., 2014). Interestingly, overexpression of $P s b P$ markedly reduced AMV replication in infected leaves, suggesting that there is a potential PsbP-mediated antiviral mechanism which was sequestered by CP-PsbP interaction (Balasubramaniam et al., 2014).

TMV 126-kD replicase associates with several CPRPs (Table 1) such as PsbO (Abbink et al., 2002), RCA and ATPsynthase $\gamma$-subunit (AtpC) (Bhat et al., 2013). Silencing of $P s b O$ results in leaf chlorosis and elevated replication of several viruses including TMV, AMV, and PVX (Abbink et al., 2002). Similarly, suppression of $A t p C$ and $R C A$ enhances the accumulation of TMV and TVCV (Bhat et al., 2013). In addition, TMV infection specifically decreased the expression levels of $A t p C, R C A$, and $P s b O$ (Abbink et al., 2002; Bhat et al., 2013). Further, silencing of RbCS enhances host susceptibility to ToMV and TMV, which is be accompanied by the reduced expression of pathogen related gene $P R-1 a$ (Zhao et al., 2013). These findings suggest that these CPRPs (RbCS, AtpC, RCA, and PsbO) play roles in plant defense against TMV, and TMV has evolved a strategy to suppress the defense of host plants for optimizing their own propagation.

The cylindrical inclusion (CI) protein of potyviruses is required for virus replication and cell-to-cell movement. CI protein from PPV and TVMV interacts with photosystem I PSI-K protein (Table 1), the product of the gene psaK in yeast (Jimenez et al., 2006). Overexpression of PPV CI reduces protein level of PSI-K while silencing or knockout of psaK enhances PPV accumulation in N. benthamiana and Arabidopsis, suggesting that 
chloroplast-localized PSI-K protein could have an antiviral role (Jimenez et al., 2006).

AltMV TGB1 can bind several chloroplast factors (Table 1), such as light harvesting chlorophyll-protein complex I subunit A4 (LhcA4), chlorophyll a/b binding protein 1 (LHB1B2), chloroplast-localized IscA-like protein (CPISCA) and chloroplast $\beta$-ATPase (CF1 $\beta$ ) (Seo et al., 2014). Among those chloroplast proteins, CF1 $\beta$ selectively binds the wild type TGB $1_{L 88}$ with high RNAi suppressor activity (Table 1) but not the natural variant TGB1 188 with reduced silencing suppressor activity (Seo et al., 2014). During infection with wild type AltMV, silencing of CF1 $\beta$ specifically causes severe necrosis without a significant change of viral RNAs, suggesting a direct role of $C F 1 \beta$ responding to TGB1 $1_{\mathrm{L} 88}$ to induce defense responses (Seo et al., 2014). Taken together, the above reports indicate that the chloroplast plays an important defense role during virus invasion.

During incompatible plant-virus interactions, some chloroplast factors also participate in plant defense against viruses. For examples, in TMV resistance gene $N$ containing tobacco, $\mathrm{N}$ receptor interacting protein 1 (NRIP1), a rhodanese sulfurtransferase which is destined to chloroplast under normal conditions, associates with both the tobacco $\mathrm{N}$ receptor and $126 \mathrm{~K}$ replicase during TMV infection; its relocation from chloroplast to cytoplasm and nucleus is required for $\mathrm{N}$-mediated resistance to TMV (Caplan et al., 2008). Moreover, depletion of $R b C S$ compromises $T m-2^{2}$ mediated extreme resistance against ToMV and TMV (Zhao et al., 2013). In addition, chloroplastlocalized calcium-sensing receptor is found to be involved in stromal $\mathrm{Ca}^{2+}$ transients and responsible for both basal resistance and $R$ gene-mediated defense (Nomura et al., 2012). These observations are consistent with the idea that chloroplasts have a critical role in plant immunity as a major site for the production for ROS, SA, and JA, important mediators of plant immunity.

Taken together, chloroplast factors participate in both basal defense and $R$ gene mediated immunity against viruses.

\section{CONCLUSIONS AND FUTURE PERSPECTIVES}

The disturbance of chloroplast structure or components is often involved in symptom development and some chloroplast proteins help viruses to fulfill their infection cycle in plants. On the other hand, chloroplast factors seem to play active roles in plant defense against viruses. This is consistent with the idea that ROS, SA, and JA are produced in chloroplast (Heiber et al., 2014).

So far, some chloroplast factors involved in virus symptomology, infection cycle or antiviral defense have been identified, and their roles in virus infection have been characterized. Some findings can explain phenomena observed in early reports. However, our understanding about chloroplastvirus interaction is still quite poor. In the future, we need to identify more chloroplast factors that take part in virus infection and plant defense against viruses, to unravel their precise role and functional mechanism during plant-virus interactions, to investigate how viruses modulate expression of CPRGs and chloroplast-derived signaling to affect plant response to viruses, and how viral factors or defense signals traffic between chloroplast and other cellular compartments. Further progress in understanding of chloroplast-virus interactions will open new possibilities in controlling virus infection by regulating host factor's expression level.

\section{AUTHOR CONTRIBUTIONS}

JZ wrote most part of this manuscript. XZ helped to write this manuscript. YL, YH supervised, revised and complemented the writing.

\section{FUNDING}

This work was supported by the National Natural Science Foundation of China (31530059, 31470254, 31300134, 31270182, and 31370180), the National Basic Research Program of China (2014CB138400), the Special Fund for Agro-scientific Research in the Public Interest of China (201303028), and the China Postdoctoral Science Foundation (2014M550049), the Initial Funding of Zhejiang Academy of Agricultural Sciences, and the Cultural Funding for Youth Talent of Zhejiang Academy of Agricultural Sciences (2015R21R08E03).

\section{ACKNOWLEDGMENTS}

We thank Mr. Oliver Terrett at Cambridge University for help in correcting the English of the manuscript.

\section{REFERENCES}

Abbink, T. E., Peart, J. R., Mos, T. N., Baulcombe, D. C., Bol, J. F., and Linthorst, H. J. (2002). Silencing of a gene encoding a protein component of the oxygenevolving complex of photosystem II enhances virus replication in plants. Virology 295, 307-319. doi: 10.1006/viro.2002.1332

Ahlquist, P. (2002). RNA-dependent RNA polymerases, viruses, and RNA silencing. Science 296, 1270-1273. doi: 10.1126/science.1069132

Ahlquist, P., Noueiry, A. O., Lee, W.-M., Kushner, D. B., and Dye, B. T. (2003). Host factors in positive-strand RNA virus genome replication. J. Virol. 77, 8181-8186. doi: 10.1128/JVI.77.15.8181-8186.2003

Alazem, M., and Lin, N.-S. (2015). Roles of plant hormones in the regulation of host-virus interactions. Mol. Plant Pathol. 16, 529-540. doi: $10.1111 / \mathrm{mpp} .12204$

Allan, A. C., Lapidot, M., Culver, J. N., and Fluhr, R. (2001). An early tobacco mosaic virus-induced oxidative burst in tobacco indicates extracellular perception of the virus coat protein. Plant Physiol. 126, 97-108. doi: 10.1104/pp.126.1.97

Allen, T. C. (1972). Subcellular responses of mesophyll cells to wild cucumber mosaic virus. Virology 47, 467-474. doi: 10.1016/0042-6822(72) 90282-6

Almási, A., Harsányi, A., and Gáborjányi, R. (2001). Photosynthetic alterations of virus infected plants. Acta Phytopathol. Entomol. Hung 36, 15-29. doi: 10.1556/APhyt.36.2001.1-2.3

Almon, E., Horowitz, M., Wang, H. L., Lucas, W. J., Zamski, E., and Wolf, S. (1997). Phloem-specific expression of the tobacco mosaic virus movement protein alters carbon metabolism and partitioning in transgenic potato plants. Plant Physiol. 115, 1599-1607. doi: 10.1104/pp.115.4.1599 
Angel, C. A., Lutz, L., Yang, X., Rodriguez, A., Adair, A., Zhang, Y., et al. (2013). The P6 protein of cauliflower mosaic virus interacts with CHUP1, a plant protein which moves chloroplasts on actin microfilaments. Virology 443, 363-374. doi: 10.1016/j.virol.2013.05.028

Angell, S. M., and Baulcombe, D. C. (1997). Consistent gene silencing in transgenic plants expressing a replicating potato virus X RNA. EMBO J. 16, 3675-3684. doi: $10.1093 /$ emboj/16.12.3675

Appiano, A., Pennazio, S., and Redolfi, P. (1978). Cytological alterations in tissues of Gomphrena globosa plants systemically infected with tomato bushy stunt virus. J. Gen. Virol. 40, 277-286. doi: 10.1099/0022-1317-40-2-277

Arnott, H. J., Rosso, S. W., and Smith, K. M. (1969). Modification of plastid ultrastructure in tomato leaf cells infected with tobacco mosaic virus. J. Ultrastruct. Res. 27, 149-167. doi: 10.1016/S0022-5320(69)90025-2

Asada, K. (2006). Production and scavenging of reactive oxygen species in chloroplasts and their functions. Plant Physiol. 141, 391-396. doi: $10.1104 /$ pp.106.082040

Asurmendi, S., Berg, R. H., Koo, J. C., and Beachy, R. N. (2004). Coat protein regulates formation of replication complexes during tobacco mosaic virus infection. Proc. Natl. Acad. Sci. U.S.A. 101, 1415-1420. doi: 10.1073/pnas.0307778101

Atreya, C. D., and Siegel, A. (1989). Localization of multiple TMV encapsidation initiation sites on rbcL gene transcripts. Virology 168, 388-392. doi: 10.1016/0042-6822(89)90280-8

Balachandran, S., Osmond, C. B., and Daley, P. F. (1994a). Diagnosis of the earliest strain-specific interactions between tobacco mosaic virus and chloroplasts of tobacco leaves in vivo by means of chlorophyll fluorescence imaging. Plant Physiol. 104, 1059-1065. doi: 10.1104/pp.104.3.1059

Balachandran, S., Osmond, C. B., and Makino, A. (1994b). Effects of two strains of tobacco mosaic virus on photosynthetic characteristics and nitrogen partitioning in leaves of Nicotiana tabacum cv Xanthi during photoacclimation under two nitrogen nutrition regimes. Plant Physiol. 104, 1043-1050. doi: 10.1104/pp.104.3.1043

Balasubramaniam, M., Kim, B.-S., Hutchens-Williams, H. M., and Loesch-Fries, L. S. (2014). The photosystem II oxygen-evolving complex protein PsbP interacts with the coat protein of alfalfa mosaic virus and inhibits virus replication. Mol. Plant. Microbe Interact 27, 1107-1118. doi: 10.1094/MPMI-02-14-0035-R

Bald, J. G. (1948). The development of amoeboid inclusion bodies of tobacco mosaic virus. Aust. J. Bot. Sci. 1, 458-463. doi: 10.1071/BI9480458

Banerjee, N., Wang, J.-Y., and Zaitlin, M. (1995). A single nucleotide change in the coat protein gene of tobacco mosaic virus is involved in the induction of severe chlorosis. Virology 207, 234-239. doi: 10.1006/viro.1995.1070

Banerjee, N., and Zaitlin, M. (1992). Import of tobacco mosaic virus coat protein into intact chloroplasts in vitro. Mol. Plant-Microbe Interact 5, 466-471. doi: 10.1094/MPMI-5-466

Bassi, M., Appiano, A., Barbieri, N., and D'Agostino, G. (1985). Chloroplast alterations induced by tomato bushy stunt virus inDatura leaves. Protoplasma 126, 233-235. doi: 10.1007/bf01281799

Baulcombe, D. C. (1999). Fast forward genetics based on virus-induced gene silencing. Curr. Opin. Plant Biol. 2, 109-113. doi: 10.1016/S13695266(99)80022-3

Bawden, F. C., and Roberts, F. M. (1947). The influence of light intensity on the susceptibility of plants to certain viruses. An. Appl. Biol. 34, 286-296. doi: 10.1111/j.1744-7348.1947.tb06364.x

Betto, E., Bassi, M., Favali, M. A., and Conti, G. G. (1972). An electron microscopic and autoradiographic study of tobacco leaves infected with the U5 strain of tobacco mosaic virus. J. Phytopathol. 75, 193-201. doi: 10.1111/j.14390434.1972.tb02616.x

Bhat, S., Folimonova, S. Y., Cole, A. B., Ballard, K. D., Lei, Z., Watson, B. S., et al. (2013). Influence of host chloroplast proteins on Tobacco mosaic virus accumulation and intercellular movement. Plant Physiol. 161, 134-147. doi: $10.1104 /$ pp. 112.207860

Boatwright, J. L., and Pajerowska-Mukhtar, K. (2013). Salicylic acid: an old hormone up to new tricks. Mol. Plant Pathol. 14, 623-634. doi: 10.1111/mpp. 12035

Bové, J., and Bové, C. (1985). Turnip yellow mosaic virus RNA replication on the chloroplast envelope. Physiol. Vég. 23, 741-748.

Brizard, J. P., Carapito, C., Delalande, F., Van Dorsselaer, A., and Brugidou, C. (2006). Proteome analysis of plant-virus interactome: comprehensive data for virus multiplication inside their hosts. Mol. Cell. Proteomics 5, 2279-2297. doi: 10.1074/mcp.M600173-MCP200

Caplan, J. L., Kumar, A. S., Park, E., Padmanabhan, M. S., Hoban, K., Modla, S., et al. (2015). Chloroplast stromules function during innate immunity. Dev. Cell 34, 45-57. doi: 10.1016/j.devcel.2015.05.011

Caplan, J. L., Mamillapalli, P., Burch-Smith, T. M., Czymmek, K., and Dinesh-Kumar, S. P. (2008). Chloroplastic protein NRIP1 mediates innate immune receptor recognition of a viral effector. Cell 132, 449-462. doi: 10.1016/j.cell.2007.12.031

Carroll, T. W. (1970). Relation of barley stripe mosaic virus to plastids. Virology 42 , 1015-1022. doi: 10.1016/0042-6822(70)90350-8

Cheng, S.-F., Huang, Y.-P., Chen, L.-H., Hsu, Y.-H., and Tsai, C.-H. (2013). Chloroplast phosphoglycerate kinase is involved in the targeting of bamboo mosaic virus to chloroplasts in Nicotiana benthamiana plants. Plant Physiol. 163, 1598-1608. doi: 10.1104/pp.113.229666

Cheng, Y.-Q., Liu, Z.-M., Xu, J., Zhou, T., Wang, M., Chen, Y.-T., et al. (2008). HC-Pro protein of sugar cane mosaic virus interacts specifically with maize ferredoxin-5 in vitro and in planta. J. Gen. Virol. 89, 2046-2054. doi: 10.1099/vir.0.2008/001271-0

Cheo, P. C. (1971). Effect in different plant species of continuous light and dark treatment on tobacco mosaic virus replicating capacity. Virology 46, 256-265. doi: 10.1016/0042-6822(71)90028-6

Chini, A., Fonseca, S., Fernández, G., Adie, B., Chico, J. M., Lorenzo, O., et al. (2007). The JAZ family of repressors is the missing link in jasmonate signalling. Nature 448, 666-671. doi: 10.1038/nature06006

Choi, C. W. (1996). Cytological modification of sorghum leaf tissues showing the early acute response to maize dwarf mosaic virus. J Plant Biol 39, 215-221.

Christov, I., Stefanov, D., Velinov, T., Goltsev, V., Georgieva, K., Abracheva, P., et al. (2007). The symptomless leaf infection with grapevine leafroll associated virus 3 in grown in vitro plants as a simple model system for investigation of viral effects on photosynthesis. J. Plant Physiol. 164, 1124-1133. doi: 10.1016/j.jplph.2005.11.016

Citovsky, V., Knorr, D., Schuster, G., and Zambryski, P. (1990). The P30 movement protein of tobacco mosaic virus is a single-strand nucleic acid binding protein. Cell 60, 637-647. doi: 10.1016/0092-8674(90)90667-4

Clemente-Moreno, M. J., Díaz-Vivancos, P., Rubio, M., Fernández-García, N., and Hernández, J. A. (2013). Chloroplast protection in plum pox virus-infected peach plants by L-2-oxo-4-thiazolidine-carboxylic acid treatments: effect in the proteome. Plant Cell Environ. 36, 640-654. doi: 10.1111/pce.12003

Cowan, G. H., Roberts, A. G., Chapman, S. N., Ziegler, A., Savenkov, E. I., and Torrance, L. (2012). The potato mop-top virus TGB2 protein and viral RNA associate with chloroplasts and viral infection induces inclusions in the plastids. Front. Plant Sci. 3:290. doi: 10.3389/fpls.2012.00290

da Graça, J. V., and Martin, M. M. (1975). Ultrastructural changes in tobacco mosaic virus-induced local lesions in Nicotiana tabacum L. cv. "Samsun NN". Physiol. Plant Pathol. 7, 287-291. doi: 10.1016/0048-4059(75)90033-8

Dardick, C. (2007). Comparative expression profiling of Nicotiana benthamiana leaves systemically infected with three fruit tree viruses. Mol. Plant Microbe Interact 20, 1004-1017. doi: 10.1094/mpmi-20-8-1004

de Graaff, M., Coscoy, L., and Jaspars, E. M. J. (1993). Localization and biochemical characterization of Alfalfa mosaic virus replication complexes. Virology 194, 878-881. doi: 10.1006/viro.1993.1335

De Stradis, A., Redinbaugh, M., Abt, J., and Martelli, G. (2005). Ultrastructure of maize necrotic streak virus infections. J. Plant Pathol. 87, 213-221. doi: 10.4454/jpp.v87i3.920

Díaz-Vivancos, P., Clemente-Moreno, M. J., Rubio, M., Olmos, E., García, J. A., Martínez-Gómez, P., et al. (2008). Alteration in the chloroplastic metabolism leads to ROS accumulation in pea plants in response to plum pox virus. J. Exp. Bot. 59, 2147-2160. doi: 10.1093/jxb/ern082

Ding, B., Haudenshield, J. S., Hull, R. J., Wolf, S., Beachy, R. N., and Lucas, W. J. (1992). Secondary plasmodesmata are specific sites of localization of the tobacco mosaic virus movement protein in transgenic tobacco plants. Plant Cell 4, 915-928. doi: 10.1105/tpc.4.8.915

Dreher, T. W. (2004). Turnip yellow mosaic virus: transfer RNA mimicry, chloroplasts and a C-rich genome. Mol. Plant Pathol. 5, 367-375. doi: 10.1111/j.1364-3703.2004.00236.x

El Fattah, A. A., El-Din, H. A. N., Abodoah, A., and Sadik, A. (2005). Occurrence of two sugarcane mosaic potyvirus strains in sugarcane. Pak. J. Biotechnol. 
2, 1-12. Available online at: http://www.pjbt.org/publications.php?year=2005\# myModal_1

Falcioni, T., Ferrio, J. P., del Cueto, A. I., Giné, J., Achón, M. Á., and Medina, V. (2014). Effect of salicylic acid treatment on tomato plant physiology and tolerance to potato virus X infection. Eur. J. Plant Pathol. 138, 331-345. doi: 10.1007/s10658-013-0333-1

Feki, S., Loukili, M. J., Triki-Marrakchi, R., Karimova, G., Old, I., Ounouna, H., et al. (2005). Interaction between tobacco ribulose-1,5-biphosphate carboxylase/oxygenase large subunit (RubisCO-LSU) and the PVY coat protein (PVY-CP). Eur. J. Plant Pathol. 112, 221-234. doi: 10.1007/s10658-004-6807-4

Filée, J., and Forterre, P. (2005). Viral proteins functioning in organelles: a cryptic origin? Trends Microbiol. 13, 510-513. doi: 10.1016/j.tim.2005.08.012

Fraser, R. S. S. (1969). Effects of two TMV strains on the synthesis and stability of chloroplast ribosomal RNA in tobacco leaves. Mol. Gen. Genet. 106, 73-79. doi: 10.1007/BF00332822

Fujiwara, T., Giesman-Cookmeyer, D., Ding, B., Lommel, S. A., and Lucas, W. J. (1993). Cell-to-cell trafficking of macromolecules through plasmodesmata potentiated by the red clover necrotic mosaic virus movement protein. Plant Cell 5, 1783-1794. doi: 10.1105/tpc.5.12.1783

Gadh, I. P. S., and Hari, V. (1986). Association of tobacco etch virus related RNA with chloroplasts in extracts of infected plants. Virology 150, 304-307. doi: 10.1016/0042-6822(86)90292-8

Gao, Q.-M., Venugopal, S., Navarre, D., and Kachroo, A. (2011). Low oleic acid-derived repression of jasmonic acid-inducible defense responses requires the WRKY50 and WRKY51 proteins. Plant Physiol. 155, 464-476. doi: 10.1104/pp.110.166876

García-Marcos, A., Pacheco, R., Manzano, A., Aguilar, E., and Tenllado, F. (2013). Oxylipin biosynthesis genes positively regulate programmed cell death during compatible infections with the synergistic pair potato virus X-potato virus $\mathrm{Y}$ and tomato spotted wilt virus. J. Virol. 87, 5769-5783. doi: 10.1128/jvi.03573-12

Garcion, C., Lohmann, A., Lamodière, E., Catinot, J., Buchala, A., Doermann, P., et al. (2008). Characterization and biological function of the ISOCHORISMATE SYNTHASE2 gene of Arabidopsis. Plant Physiol. 147, 1279-1287. doi: 10.1104/pp.108.119420

Garg, I., and Hegde, V. (2000). Biological characterization, preservation and ultrastructural studies of Andean strain of potato virus S. Indian Phytopathol. 53, 256-260. Available online at: http://epubs.icar.org.in/ejournal/index.php/ IPPJ/article/view/19306

Garnier, M., Candresse, T., and Bove, J. M. (1986). Immunocytochemical localization of TYMV-coded structural and nonstructural proteins by the protein A-gold technique. Virology 151, 100-109. doi: 10.1016/00426822(86)90107-8

Gerola, F., and Bassi, M. (1966). An electron microscopy study of leaf vein tumours from maize plants experimentally infected with maize rough dwarf virus. Caryologia 19, 13-40. doi: 10.1080/00087114.1966.10796201

Granett, A., and Shalla, T. (1970). Discrepancies in the intracellular behavior of three strains of tobacco mosaic virus, two of which are serologically indistinguishable. Phytopathology 60, 419-425. doi: 10.1094/Phyto-60-419

Gröning, B. R., Abouzid, A., and Jeske, H. (1987). Single-stranded DNA from abutilon mosaic virus is present in the plastids of infected Abutilon sellovianum. Proc. Natl. Acad. Sci. U.S.A. 84, 8996-9000.

Gröning, B. R., Frischmuth, T., and Jeske, H. (1990). Replicative form DNA of abutilon mosaic virus is present in plastids. Mol. Gen. Genet. 220, 485-488. doi: 10.1007/bf00391759

Gunasinghe, U., and Berger, P. (1991). Association of potato virus Y gene products with chloroplasts in tobacco. Mol. Plant. Microbe Interact 4, 452-457. doi: 10.1094/MPMI-4-452

Guo, D.-P., Guo, Y.-P., Zhao, J.-P., Liu, H., Peng, Y., Wang, Q.-M., et al. (2005), Photosynthetic rate and chlorophyll fluorescence in leaves of stem mustard (Brassica juncea var. tsatsai) after turnip mosaic virus infection. Plant Sci. 168, 57-63. doi: 10.1016/j.plantsci.2004.07.019

Guo, X., Zhu, X., Zhang, J., and Guo, Y. (2004). Changes of cell ultrastructure of maize leaves infected by maize dwarf mosaic virus. Sci. Agric. Sin. 37, 72-75. Available online at: http://en.cnki.com.cn/Article_en/CJFDTotalZNYK200401010.htm

Gu, Y., and Dong, X. (2015). Stromules: signal conduits for plant immunity. Dev. Cell 34, 3-4. doi: 10.1016/j.devcel.2015.06.018

Hakmaoui, A., Pérez-Bueno, M. L., García-Fontana, B., Camejo, D., Jiménez, A., Sevilla, F., et al. (2012). Analysis of the antioxidant response of Nicotiana benthamiana to infection with two strains of pepper mild mottle virus. J. Exp. Bot. 63, 5487-5496. doi: 10.1093/jxb/ers212

Hall, A. E., and Loomis, R. S. (1972). An explanation for the difference in photosynthetic capabilities of healthy and beet yellows virus-infected sugar beets (Beta vulgaris L.). Plant Physiol. 50, 576-580. doi: 10.1104/pp.50.5.576

Hatta, T., and Matthews, R. E. F. (1974). The sequence of early cytological changes in Chinese cabbage leaf cells following systemic infection with turnip yellow mosaic virus. Virology 59, 383-396. doi: 10.1016/0042-6822(74)90452-8

Heaton, L. A., Lee, T. C., Wei, N., and Morris, T. J. (1991). Point mutations in the turnip crinkle virus capsid protein affect the symptoms expressed by Nicotiana benthamiana. Virology 183, 143-150. doi: 10.1016/0042-6822(91)90127-W

Hedtke, B., Börner, T., and Weihe, A. (1997). Mitochondrial and chloroplast phage-type RNA polymerases in Arabidopsis. Science 277, 809-811. doi: 10.1126/science.277.5327.809

Heiber, I., Cai, W., and Baier, M. (2014). Linking chloroplast antioxidant defense to carbohydrate availability: the transcript abundance of stromal ascorbate peroxidase is sugar-controlled via ascorbate biosynthesis. Mol. Plant 7, 58-70. doi: $10.1093 / \mathrm{mp} / \mathrm{sst} 154$

Helms, K. (1965). Role of temperature and light in lesion development of tobacco mosaic virus. Nature 205, 421-422. doi: 10.1038/205421a0

Helms, K., and McIntyre, G. A. (1967). Light-induced susceptibility of Phaseolus vulgaris L. to tobacco mosaic virus infection. I. Effects of light intensity, temperature, and the length of the preinoculation dark period. Virology 31, 191-196. doi: 10.1016/0042-6822(67)90162-6

Herbers, K., Takahata, Y., Melzer, M., Mock, H. P., Hajirezaei, M., and Sonnewald, U. (2000). Regulation of carbohydrate partitioning during the interaction of potato virus Y with tobacco. Mol. Plant Pathol. 1, 51-59. doi: 10.1046/j.13643703.2000.00007.x

Hernández, J. A., Díaz-Vivancos, P., Rubio, M., Olmos, E., Ros-Barceló, A., and Martínez-Gómez, P. (2006). Long-term plum pox virus infection produces an oxidative stress in a susceptible apricot, Prunus armeniaca, cultivar but not in a resistant cultivar. Plant Physiol. 126, 140-152. doi: 10.1111/j.13993054.2005.00581.x

Hodgson, R. A., Beachy, R. N., and Pakrasi, H. B. (1989). Selective inhibition of photosystem II in spinach by tobacco mosaic virus: an effect of the viral coat protein. FEBS Lett. 245, 267-270. doi: 10.1016/0014-5793(89)80234-0

Hohn, T., Fütterer, J., and Hull, R. (1997). The proteins and functions of plant pararetroviruses: knowns and unknowns. Crit. Rev. Plant Sci. 16, 133-161. doi: 10.1080/07352689709701947

Huh, S. U., Kim, M. J., Ham, B. K., and Paek, K. H. (2011). A zinc finger protein Tsipl controls cucumber mosaic virus infection by interacting with the replication complex on vacuolar membranes of the tobacco plant. New Phytol. 191, 746-762. doi: 10.1111/j.1469-8137.2011.03717.x

Imlau, A., Truernit, E., and Sauer, N. (1999). Cell-to-cell and long-distance trafficking of the green fluorescent protein in the phloem and symplastic unloading of the protein into sink tissues. Plant Cell 11, 309-322. doi: 10.1105/tpc.11.3.309

Jakubiec, A., Notaise, J., Tournier, V., Héricourt, F., Block, M. A., Drugeon, G., et al. (2004). Assembly of turnip yellow mosaic virus replication complexes: interaction between the proteinase and polymerase domains of the replication proteins. J. Virol. 78, 7945-7957. doi: 10.1128/JVI.78.15.7945-7957.2004

Jang, C., Seo, E.-Y., Nam, J., Bae, H., Gim, Y. G., Kim, H. G., et al. (2013). Insights into alternanthera mosaic virus TGB3 functions: interactions with Nicotiana benthamiana PsbO correlate with chloroplast vesiculation and veinal necrosis caused by TGB3 over-expression. Front. Plant Sci. 4:5. doi: 10.3389/fpls.2013.00005

Jimenez, I., Lopez, L., Alamillo, J. M., Valli, A., and Garcia, J. A. (2006). Identification of a plum pox virus CI-interacting protein from chloroplast that has a negative effect in virus infection. Mol. Plant-Microbe Interact 19, 350-358. doi: 10.1094/MPMI-19-0350

Jin, Y., Ma, D., Dong, J., Li, D., Deng, C., Jin, J., et al. (2007). The HC-Pro protein of potato virus $\mathrm{Y}$ interacts with NtMinD of tobacco. Mol. Plant-Microbe Interact 20, 1505-1511. doi: 10.1094/mpmi-20-12-1505

Kaido, M., Abe, K., Mine, A., Hyodo, K., Taniguchi, T., Taniguchi, H., et al. (2014). Gapdh-A recruits a plant virus movement protein to cortical virus replication complexes to facilitate viral cell-to-cell movement. PLoS Path. 10:e1004505. doi: 10.1371/journal.ppat.1004505

Kitajima, E., and Costa, A. (1973). Aggregates of chloroplasts in local lesions induced in Chenopodium quinoa Wild. by turnip 
mosaic virus. J. Gen. Virol. 20, 413-416. doi: 10.1099/0022-131720-3-413

Kobayashi, Y., Dokiya, Y., and Sugita, M. (2001). Dual targeting of phage-type RNA polymerase to both mitochondria and plastids is due to alternative translation initiation in single transcripts. Biochem. Biophys. Res. Commun. 289, 1106-1113. doi: 10.1006/bbrc.2001.6130

Kong, L., Wu, J., Lu, L., Xu, Y., and Zhou, X. (2014). Interaction between rice stripe virus disease-specific protein and host PsbP enhances virus symptoms. Mol. Plant 7, 691-708. doi: 10.1093/mp/sst158

Kozar, F. E., and Sheludko, Y. M. (1969). Ultrastructure of potato and Datura stramonium plant cells infected with potato virus X. Virology 38, 220-229. doi: 10.1016/0042-6822(69)90363-8

Krenz, B., Jeske, H., and Kleinow, T. (2012). The induction of stromule formation by a plant DNA-virus in epidermal leaf tissues suggests a novel intra- and intercellular macromolecular trafficking route. Front. Plant Sci. 3:291. doi: 10.3389/fpls.2012.00291

Krenz, B., Windeisen, V., Wege, C., Jeske, H., and Kleinow, T. (2010). A plastidtargeted heat shock cognate $70 \mathrm{kDa}$ protein interacts with the abutilon mosaic virus movement protein. Virology 401, 6-17. doi: 10.1016/j.virol.2010.02.011

Kundu, S., Chakraborty, D., Kundu, A., and Pal, A. (2013). Proteomics approach combined with biochemical attributes to elucidate compatible and incompatible plant-virus interactions between Vigna mungo and mungbean yellow mosaic India virus. Proteome Sci. 11:15. doi: 10.1186/1477-5956-11-15

Kunkel, B. N., and Brooks, D. M. (2002). Cross talk between signaling pathways in pathogen defense. Curr. Opin. Plant Biol. 5, 325-331. doi: 10.1016/S13695266(02)00275-3

Kupeevicz, V. (1947). The physiology of the diseased plant in relation to the general questions of parasitism. Moscow; Leningrad: USSR Academy of Sciences.

Kyseláková, H., Prokopová, J., Nauš, J., Novák, O., Navrátil, M., Šafářová, D., et al. (2011). Photosynthetic alterations of pea leaves infected systemically by pea enation mosaic virus: a coordinated decrease in efficiencies of $\mathrm{CO}_{2}$ assimilation and photosystem II photochemistry. Plant Physiol. Biochem. 49, 1279-1289. doi: 10.1016/j.plaphy.2011.08.006

Lafleche, D., Bové, C., Dupont, G., Mouches, C., Astier, T., Garnier, M., et al. (1972). Site of viral RNA replication in the cells of higher plants: TYMV-RNA synthesis on the chloroplast outer membrane system. Proc. Fed. Eur. Biochem. Soc. $27,43-71$.

Laliberté, J.-F., and Sanfaçon, H. (2010). Cellular remodeling during plant virus infection. Annu. Rev. Phytopathol. 48, 69-91. doi: 10.1146/annurev-phyto073009-114239

Lazarowitz, S. G., and Beachy, R. N. (1999). Viral movement proteins as probes for intracellular and intercellular trafficking in plants. Plant Cell 11, 535-548. doi: 10.1105/tpc.11.4.535

Lehto, K., Tikkanen, M., Hiriart, J.-B., Paakkarinen, V., and Aro, E.-M. (2003). Depletion of the photosystem II core complex in mature tobacco leaves infected by the flavum strain of tobacco mosaic virus. Mol. Plant-Microbe Interact 16, 1135-1144. doi: 10.1094/mpmi.2003.16.12.1135

Lemos, M., Xiao, Y., Bjornson, M., Wang, J.-Z., Hicks, D., Souza, A. D., et al. (2016). The plastidial retrograde signal methyl erythritol cyclopyrophosphate is a regulator of salicylic acid and jasmonic acid crosstalk. J. Exp. Bot. 67, 1557-1566. doi: 10.1093/jxb/erv550

Lesemann, D.-E. (1991). "Specific cytological alterations in virus-infected plant cells," in Electron Microscopy of Plant Pathogens, eds K. Mendgen and D.-E. Lesemann (Berlin; Heidelberg: Springer), 147-159.

Li, J., Brader, G., and Palva, E. T. (2004). The WRKY70 transcription factor: a node of convergence for jasmonate-mediated and salicylate-mediated signals in plant defense. Plant Cell 16, 319-331. doi: 10.1105/tpc.016980

Li, Y. H., Hong, J., Xue, L., Yang, Y., Zhou, X. P., and Jiang, D. A. (2006). Effects of Broad bean wilt virus 2 isolate infection on photosynthetic activities and chloroplast ultrastructure in broad bean leaves. J. Plant Physiol. Mol. Biol. 32, 490-496. doi: 10.3321/j.issn:1671-3877.2006.04.014

Li, Y., Wu, M. Y., Song, H. H., Hu, X., and Qiu, B. S. (2005). Identification of a tobacco protein interacting with tomato mosaic virus coat protein and facilitating long-distance movement of virus. Arch. Virol. 150, 1993-2008. doi: 10.1007/s00705-005-0554-5

Liang, D., Ye, Y., Shi, D., Kang, L., and Tian, B. (1998). The role of viral coat protein in the induction of mosaic symptoms in tobacco. Sci. Sin. Vitae 28, 251-256. doi: 10.1360/zc1998-28-3-251
Lim, H.-S., Vaira, A. M., Bae, H., Bragg, J. N., Ruzin, S. E., Bauchan, G. R., et al. (2010). Mutation of a chloroplast-targeting signal in alternanthera mosaic virus TGB3 impairs cell-to-cell movement and eliminates long-distance virus movement. J. Gen. Virol. 91, 2102-2115. doi: 10.1099/vir.0.019448-0

Lindbeck, A. G. C., Dawson, W. O., and Thomson, W. W. (1991). Coat proteinrelated polypeptides from in vitro tobacco mosaic virus coat protein mutants do not accumulate in the chloroplasts of directly inoculated leaves. Mol. Plant Microbe Interact. 4, 89-94. doi: 10.1094/MPMI-4-089

Lindbeck, A. G. C., Lewandowski, D. J., Culver, J. N., Thomson, W. W., and Dawson, W. O. (1992). Mutant coat protein of tobacco mosaic virus induces acute chlorosis in expanded and developing tobacco leaves. Mol. Plant-Microbe Interact 5, 235-241. doi: 10.1094/MPMI-5-235

Lin, J.-W., Ding, M.-P., Hsu, Y.-H., and Tsai, C.-H. (2007). Chloroplast phosphoglycerate kinase, a gluconeogenetic enzyme, is required for efficient accumulation of bamboo mosaic virus. Nucleic Acids Res. 35, 424-432. doi: 10.1093/nar/gkl1061

Lin, L., Luo, Z., Yan, F., Lu, Y., Zheng, H., and Chen, J. (2011). Interaction between potyvirus $\mathrm{P} 3$ and ribulose-1,5-bisphosphate carboxylase/oxygenase (RubisCO) of host plants. Virus Genes 43, 90-92. doi: 10.1007/s11262-011-0596-6

Lin, N.-S., and Langenberg, W. G. (1984). Distribution of barley stripe mosaic virus protein in infected wheat root and shoot tips. J. Gen. Virol. 65, 2217-2224. doi: 10.1099/0022-1317-65-12-2217

Lin, N.-S., and Langenberg, W. G. (1985). Peripheral vesicles in proplastids of barley stripe mosaic virus-infected wheat cells contain double-stranded RNA. Virology 142, 291-298. doi: 10.1016/0042-6822(85)90337-X

Liu, J., Yang, J., Bi, H., and Zhang, P. (2014). Why mosaic? Gene expression profiling of African cassava mosaic virus-infected cassava reveals the effect of chlorophyll degradation on symptom development. J. Integr. Plant Biol. 56, 122-132. doi: 10.1111/jipb.12133

Liu, K.-C., and Boyle, J. S. (1972). Intracellular morphology of two tobacco mosaic virus strains in, and cytological responses of, systemically susceptible potato plants. Phytopathology 62, 1303-1311. doi: 10.1094/Phyto-62-1303

Lucas, W. J., Olesinski, A., Hull, R. J., Haudenshield, J. S., Deom, C. M., Beachy, R. N., et al. (1993). Influence of the tobacco mosaic-virus 30-kda movement protein on carbon metabolism and photosynthate partitioning in transgenic tobacco plants. Planta 190, 88-96. doi: 10.1007/BF00195679

Lu, J., Du, Z.-X., Kong, J., Chen, L.-N., Qiu, Y.-H., Li, G.-F., et al. (2012). Transcriptome analysis of Nicotiana tabacum infected by cucumber mosaic virus during systemic symptom development. PLoS ONE 7:e43447. doi: 10.1371/journal.pone.0043447

Mahgoub, H. A., Wipf-Scheibel, C., Delécolle, B., Pitrat, M., Dafalla, G., and Lecoq, H. (1997). Melon rugose mosaic virus: characterization of an isolate from Sudan and seed transmission in melon. Plant Dis. 81, 656-660. doi: 10.1094/PDIS.1997.81.6.656

Mandahar, C. L., and Garg, I. D. (1972). Effect of cucumber mosaic virus on chlorophyll content, photosynthesis, respiration and carbohydrates of infected Luffa aegyptiaca Mill. J. Phytopathol. 75, 181-186. doi: 10.1111/j.14390434.1972.tb02612.x

Manfre, A., Glenn, M., Nunez, A., Moreau, R., and Dardick, C. (2011). Light quantity and photosystem function mediate host susceptibility to turnip mosaic virus via a salicylic acid-independent mechanism. Mol. Plant-Microbe Interact 24, 315-327. doi: 10.1094/MPMI-08-10-0191

Martelli, G. P., and Russo, M. (1973). Electron microscopy of artichoke mottled crinkle virus in leaves of Chenopodium quinoa Willd. J. Ultrastruct. Res. 42, 93-107. doi: 10.1016/S0022-5320(73)80009-7

Martínez de Alba, A. E., Flores, R., and Hernández, C. (2002). Two chloroplastic viroids induce the accumulation of small RNAs associated with post-transcriptional gene silencing. J. Virol. 76, 13094-13096. doi: 10.1128/jvi.76.24.13094-13096.2002

Martin, M. T., Cervera, M. T., and Garcia, J. A. (1995). Properties of the active plum pox potyvirus RNA polymerase complex in defined glycerol gradient fractions. Virus Res. 37, 127-137. doi: 10.1016/0168-1702(95)00028-O

Más, P., and Beachy, R. N. (1998). Distribution of TMV movement protein in single living protoplasts immobilized in agarose. Plant J. 15, 835-842. doi: 10.1046/j.1365-313X.1998.00253.x

Más, P., and Beachy, R. N. (2000). Role of microtubules in the intracellular distribution of tobacco mosaic virus movement protein. Proc. Natl. Acad. Sci. U.S.A. 97, 12345-12349. doi: 10.1073/pnas.97.22.12345 
Matsushita, K. (1965). Tobacco mosaic virus in chloroplast and cytoplasm of infected tobacco leaf. Plant Cell Physiol. 6, 1-6.

Matthews, R. E. F. (1953). Factors affecting the production of local lesions by plant viruses. Ann. Appl. Biol. 40, 556-565. doi: 10.1111/j.1744-7348.1953.tb02393.x

Mayhew, D. E., and Ford, R. E. (1974). Detection of ribonuclease-resistant RNA in chloroplasts of corn leaf tissue infected with maize dwarf mosaic virus. Virology 57, 503-509. doi: 10.1016/0042-6822(74)90189-5

Ma, Y., Zhou, T., Hong, Y., Fan, Z., and Li, H. (2008). Decreased level of ferredoxin I in tobacco mosaic virus-infected tobacco is associated with development of the mosaic symptom. Physiol. Mol. Plant Pathol. 72, 39-45. doi: 10.1016/j.pmpp.2008.05.004

Mazidah, M., Lau, W. H., Yusoff, K., Habibuddin, H., and Tan, Y. H. (2012). Ultrastructural features of Catharanthus roseus leaves infected with cucumber mosaic virus. Pertanika J. Trop. Agric. Sci. 35, 85-92. Available online at: https:// www.cabdirect.org/cabdirect/abstract/20133203498

McClintock, K., Lamarre, A., Parsons, V., Laliberté, J.-F., and Fortin, M. G. (1998). Identification of a $37 \mathrm{kDa}$ plant protein that interacts with the turnip mosaic potyvirus capsid protein using anti-idiotypic-antibodies. Plant Mol. Biol. 37, 197-204. doi: 10.1023/a:1005916917228

McMullen, C., Gardner, W., and Myers, G. (1978). Aberrant plastids in barley leaf tissue infected with barley stripe mosaic virus. Phytopathology 68, 317-325. doi: 10.1094/Phyto-68-317

Mel'nichuk, M. D., Kozhukalo, V. E., D’Iachkova, O. A., Sytnik, S. K., Alekseenko, I. P., and Smirnova, S. A. (2002). Effect of tobacco mosaic virus on the ultrastructure of leaf mesophyll cells of the pepper Capsicuum anuum L. Mikrobiol. Z. 64, 35-40.

Mochizuki, T., Ogata, Y., Hirata, Y., and Ohki, S. T. (2014a). Quantitative transcriptional changes associated with chlorosis severity in mosaic leaves of tobacco plants infected with cucumber mosaic virus. Mol. Plant Pathol. 15, 242-254. doi: $10.1111 / \mathrm{mpp} .12081$

Mochizuki, T., and Ohki, S. (2011). Single amino acid substitutions at residue 129 in the coat protein of cucumber mosaic virus affect symptom expression and thylakoid structure. Arch. Virol. 156, 881-886. doi: 10.1007/s00705-010-0910-y

Mochizuki, T., Yamazaki, R., Wada, T., and Ohki, S. T. (2014b). Coat protein mutations in an attenuated cucumber mosaic virus encoding mutant $2 \mathrm{~b}$ protein that lacks RNA silencing suppressor activity induces chlorosis with photosynthesis gene repression and chloroplast abnormalities in infected tobacco plants. Virology 456-457, 292-299. doi: 10.1016/j.virol.2014.04.010

Mohamed, N. A. (1973). Some effects of systemic infection by tomato spotted wilt virus on chloroplasts of Nicotiana tabacum leaves. Physiol. Plant Pathol. 3, 509-516. doi: 10.1016/0048-4059(73)90061-1

Moline, H. E. (1973). Ultrastructure of Datura stramonium leaves infected with the physalis mottle strain of belladonna mottle virus. Virology 56, 123-133. doi: 10.1016/0042-6822(73)90292-4

Montasser, M., and Al-Ajmy, A. (2015). Histopathology for the influence of CMV infection on tomato cellular structures. FASEB J. 29(Suppl.):887.4. Available online at: http://www.fasebj.org/content/29/1_Supplement/887.4.short

Moshe, A., Pfannstiel, J., Brotman, Y., Kolot, M., Sobol, I., Czosnek, H., et al. (2012). Stress responses to tomato yellow leaf curl virus (TYLCV) infection of resistant and susceptible tomato plants are different. Metabolomics S1:006. doi: 10.4172/2153-0769.S1-006

Muhlenbock, P., Szechynska-Hebda, M., Plaszczyca, M., Baudo, M., Mateo, A., Mullineaux, P. M., et al. (2008). Chloroplast signaling and LESION SIMULATING DISEASE1 regulate crosstalk between light acclimation and immunity in Arabidopsis. Plant Cell 20, 2339-2356. doi: 10.1105/tpc.108.059618

Musetti, R., Bruni, L., and Favali, M. A. (2002). Cytological modifications in maize plants infected by barley yellow dwarf virus and maize dwarf mosaic virus. Micron 33, 681-686. doi: 10.1016/S0968-4328(02)00020-3

Naderi, M., and Berger, P. (1997a). Effects of chloroplast targeted potato virus Y coat protein on transgenic plants. Physiol. Mol. Plant Pathol. 50, 67-83. doi: 10.1006/pmpp.1996.0071

Naderi, M., and Berger, P. (1997b). Pathogenesis-related protein 1a is induced in potato virus Y-infected plants as well as by coat protein targeted to chloroplasts. Physiol. Mol. Plant Pathol. 51, 41-44. doi: 10.1006/pmpp.1997.0101

Naidu, R., Krishnan, M., Nayudu, M., and Gnanam, A. (1984a). Studies on peanut green mosaic virus infected peanut (Arachis hypogaea L.) leaves. II. Chlorophyll-protein complexes and polypeptide composition of thylakoid membranes. Physiol. Plant Pathol. 25, 191-198. doi: 10.1016/0048 4059(84)90057-2

Naidu, R., Krishnan, M., Nayudu, M., and Gnanam, A. (1986). Studies on peanut green mosaic virus infected peanut (Arachis hypogaea L.) leaves. III. Changes in the polypeptides of photosystem II particles. Physiol. Mol. Plant Pathol. 29, 53-58. doi: 10.1016/S0048-4059(86)80037-6

Naidu, R., Krishnan, M., Ramanujam, P., Gnanam, A., and Nayudu, M. (1984b). Studies on peanut green mosaic virus infected peanut (Arachis hypogaea L.) leaves. I. Photosynthesis and photochemical reactions. Physiol. Plant Pathol. 25, 181-190. doi: 10.1016/0048-4059(84)90056-0

Navarro, B., Gisel, A., Rodio, M. E., Delgado, S., Flores, R., and Di Serio, F. (2012). Small RNAs containing the pathogenic determinant of a chloroplast-replicating viroid guide the degradation of a host mRNA as predicted by RNA silencing. Plant J. 70, 991-1003. doi: 10.1111/j.1365-313X.2012.04940.x

Neeleman, L., Van Der Kuyl, A. C., and Bol, J. F. (1991). Role of alfalfa mosaic virus coat protein gene in symptom formation. Virology 181, 687-693. doi: 10.1016/0042-6822(91)90902-N

Nomura, H., Komori, T., Uemura, S., Kanda, Y., Shimotani, K., Nakai, K., et al. (2012). Chloroplast-mediated activation of plant immune signalling in Arabidopsis. Nat. Commun. 3, 926. doi: 10.1038/ncomms1926

Ohnishi, J., Hirai, K., Kanda, A., Usugi, T., Meshi, T., and Tsuda, S. (2009). The coat protein of tomato mosaic virus $\mathrm{L}_{11} \mathrm{Y}$ is associated with virus-induced chlorosis on infected tobacco plants. J. Gen. Plant Pathol. 75, 297-306. doi: 10.1007/s10327-009-0177-x

Oikawa, K., Kasahara, M., Kiyosue, T., Kagawa, T., Suetsugu, N., Takahashi, F., et al. (2003). CHLOROPLAST UNUSUAL POSITIONING1 is essential for proper chloroplast positioning. Plant Cell 15, 2805-2815. doi: $10.1105 /$ tpc. 016428

Oikawa, K., Yamasato, A., Kong, S.-G., Kasahara, M., Nakai, M., Takahashi, F., et al. (2008). Chloroplast outer envelope protein CHUP1 is essential for chloroplast anchorage to the plasma membrane and chloroplast movement. Plant Physiol. 148, 829-842. doi: 10.1104/pp.108.123075

Olesinski, A. A., Almon, E., Navot, N., Perl, A., Galun, E., Lucas, W. J., et al. (1996). Tissue-specific expression of the tobacco mosaic virus movement protein in transgenic potato plants alters plasmodesmal function and carbohydrate partitioning. Plant Physiol. 111, 541-550. doi: 10.1104/pp.111.2.541

Olesinski, A. A., Lucas, W. J., Galun, E., and Wolf, S. (1995). Pleiotropic effects of tobacco-mosaic-virus movement protein on carbon metabolism in transgenic tobacco plants. Planta 197, 118-126. doi: 10.1007/BF00239947

Otulak, K., Chouda, M., Bujarski, J., and Garbaczewska, G. (2015). The evidence of tobacco rattle virus impact on host plant organelles ultrastructure. Micron 70 , 7-20. doi: 10.1016/j.micron.2014.11.007

Ouibrahim, L., Mazier, M., Estevan, J., Pagny, G., Decroocq, V., Desbiez, C., et al. (2014). Cloning of the Arabidopsis rwm1 gene for resistance to watermelon mosaic virus points to a new function for natural virus resistance genes. Plant J. 79, 705-716. doi: 10.1111/tpj.12586

Owen, P. C. (1957a). The effect of infection with tobacco etch virus on the rates of respiration and photosynthesis of tobacco leaves. Ann. Appl. Biol. 45, 327-331. doi: 10.1111/j.1744-7348.1957.tb00474.x

Owen, P. C. (1957b). The effects of infection with tobacco mosaic virus on the photosynthesis of tobacco leaves. Ann. Appl. Biol. 45, 456-461. doi: 10.1111/j.1744-7348.1957.tb05882.x

Owen, P. C. (1958). Photosynthesis and respiration rates of leaves of Nicotiana glutinosa infected with tobacco mosaic virus and of $N$. tabacum infected with potato virus X. Ann. Appl. Biol. 46, 198-204. doi: 10.1111/j.17447348.1958.tb02196.x

Papaefthimiou, I., Hamilton, A., Denti, M., Baulcombe, D., Tsagris, M., and Tabler, M. (2001). Replicating potato spindle tuber viroid RNA is accompanied by short RNA fragments that are characteristic of post-transcriptional gene silencing. Nucleic Acids Res. 29, 2395-2400. doi: 10.1093/nar/29. 11.2395

Pérez-Bueno, M. L., Rahoutei, J., Sajnani, C., García-Luque, I., and Barón, M. (2004). Proteomic analysis of the oxygen-evolving complex of photosystem II under biotec stress: studies on Nicotiana benthamiana infected with tobamoviruses. Proteomics 4, 418-425. doi: 10.1002/pmic.200300655

Pineda, M., Sajnani, C., and Barón, M. (2010). Changes induced by the pepper mild mottle tobamovirus on the chloroplast proteome of Nicotiana benthamiana. Photosynthesis Res. 103, 31-45. doi: 10.1007/s11120-009-9499-y 
Pompe-Novak, M., Wrischer, M., and Ravnikar, M. (2001). Ultrastructure of chloroplasts in leaves of potato plants infected by potato virus $\mathrm{Y}_{\mathrm{NTN}}$. Phyton 41, 215-226. Available online at: http://cat.inist.fr/?aModele=afficheN\&cpsidt= 13742909

Prod'homme, D., Jakubiec, A., Tournier, V., Drugeon, G., and Jupin, I. (2003). Targeting of the Turnip Yellow Mosaic Virus 66K replication protein to the chloroplast envelope is mediated by the 140K protein. J. Virol. 77, 9124-9135. doi: 10.1128/JVI.77.17.9124-9135.2003

Prod'homme, D., Le Panse, S., Drugeon, G., and Jupin, I. (2001). Detection and subcellular localization of the Turnip Yellow Mosaic Virus 66K replication protein in infected cells. Virology 281, 88-101. doi: 10.1006/viro.2000.0769

Qiao, Y., Li, H. F., Wong, S. M., and Fan, Z. F. (2009). Plastocyanin transit peptide interacts with potato virus $\mathrm{X}$ coat protein, while silencing of plastocyanin reduces coat protein accumulation in chloroplasts and symptom severity in host plants. Mol. Plant Microbe Interact 22, 1523-1534. doi: 10.1094/mpmi-22$12-1523$

Radwan, D. E. M., Ali Fayez, K., Younis Mahmoud, S., Hamad, A., and Lu, G. (2006). Salicylic acid alleviates growth inhibition and oxidative stress caused by zucchini yellow mosaic virus infection in Cucurbita pepo leaves. Physiol. Mol. Plant Pathol. 69, 172-181. doi: 10.1016/j.pmpp.2007.04.004

Radwan, D. E. M., Fayez, K. A., Younis Mahmoud, S., Hamad, A., and Lu, G. (2007). Physiological and metabolic changes of Cucurbita pepo leaves in response to zucchini yellow mosaic virus (ZYMV) infection and salicylic acid treatments. Plant Physiol. Biochem. 45, 480-489. doi: 10.1016/j.plaphy.2007.03.002

Radwan, D. E. M., Lu, G., Fayez, K. A., and Mahmoud, S. Y. (2008). Protective action of salicylic acid against bean yellow mosaic virus infection in Vicia faba leaves. J. Plant Physiol. 165, 845-857. doi: 10.1016/j.jplph.2007.07.012

Rahoutei, J., García-Luque, I., and Barón, M. (2000). Inhibition of photosynthesis by viral infection: effect on PSII structure and function. Physiol. Plant. 110, 286-292. doi: 10.1034/j.1399-3054.2000.110220.x

Regenmortel, M. H. V. V., and Fraenkel-Conrat, H. (1986). The Plant Viruses Vol. 2, The Rod-shaped Plant Viruses. New York, NY, London: Springer Science \& Business Media.

Reimann-Philipp, U., and Beachy, R. N. (1993). Coat protein-mediated resistance in transgenic tobacco expressing the tobacco mosaic virus coat protein from tissue-specific promoters. Mol. Plant-Microbe Interact 6, 323-330. doi: 10.1098/rstb.1999.0418

Reinero, A., and Beachy, R. N. (1986). Association of TMV coat protein with chloroplast membranes in virus-infected leaves. Plant Mol. Biol. 6, 291-301. doi: 10.1007/BF00034936

Reinero, A., and Beachy, R. N. (1989). Reduced photosystem II activity and accumulation of viral coat protein in chloroplasts of leaves infected with tobacco mosaic virus. Plant Physiol. 89, 111-116. doi: 10.1104/pp.89.1.111

Roberts, P. L., and Wood, K. R. (1982). Effects of a severe (P6) and a mild (W) strain of cucumber mosaic virus on tobacco leaf chlorophyll, starch and cell ultrastructure. Physiol. Plant Pathol. 21, 31-37. doi: 10.1016/00484059(82)90005-4

Rochon, D. A., and Siegel, A. (1984). Chloroplast DNA transcripts are encapsidated by tobacco mosaic virus coat protein. Proc. Natl. Acad. Sci. U.S.A. 81, $1719-1723$.

Rodio, M.-E., Delgado, S., De Stradis, A., Gómez, M.-D., Flores, R., and Di Serio, F. (2007). A viroid RNA with a specific structural motif inhibits chloroplast development. Plant Cell 19, 3610-3626. doi: 10.1105/tpc.106.049775

Rodriguez, A., Angel, C. A., Lutz, L., Leisner, S. M., Nelson, R. S., and Schoelz, J. E. (2014). Association of the P6 protein of cauliflower mosaic virus with plasmodesmata and plasmodesmal proteins. Plant Physiol. 19:249250. doi: 10.1104/pp.114.249250

Rodríguez, M., Muñoz, N., Lenardon, S., and Lascano, R. (2012). The chlorotic symptom induced by sunflower chlorotic mottle virus is associated with changes in redox-related gene expression and metabolites. Plant Sci. 196, 107-116. doi: 10.1016/j.plantsci.2012.08.008

Rohozinski, J., and Hancock, J. M. (1996). Do light-induced pH changes within the chloroplast drive turnip yellow mosaic virus assembly? J. Gen. Virol. 77(Pt 2), 163-165. doi: 10.1099/0022-1317-77-2-163

Ryabov, E. V., Robinson, D. J., and Taliansky, M. E. (1999). A plant virus-encoded protein facilitates long-distance movement of heterologous viral RNA. Proc. Natl. Acad. Sci. U.S.A. 96, 1212-1217. doi: 10.1073/pnas.96.4.1212
Satoh, K., Kondoh, H., Sasaya, T., Shimizu, T., Choi, I.-R., Omura, T., et al. (2010). Selective modification of rice (Oryza sativa) gene expression by rice stripe virus infection. J. Gen. Virol. 91, 294-305. doi: 10.1099/vir.0.015990-0

Schaller, A., and Stintzi, A. (2009). Enzymes in jasmonate biosynthesis Structure, function, regulation. Phytochemistry 70, 1532-1538. doi: 10.1016/j.phytochem.2009.07.032

Schnablová, R., Synková, H., and Čeřovská, N. (2005). The influence of potato virus $\mathrm{Y}$ infection on the ultrastructure of Pssu-ipt transgenic tobaccol. Int. J. Plant Sci. 166, 713-721. doi: 10.1086/431807

Schuchalter-Eicke, G., and Jeske, H. (1983). Seasonal changes in the chloroplast ultrastructure in abutilon mosaic virus (AbMV) infected Abutilon spec. (Malvaceae). J. Phytopathol. 108, 172-184. doi: 10.1111/j.1439-0434.1983.tb00576.x

Seidler, A. (1996). The extrinsic polypeptides of Photosystem II. Biochim. Biophys. Acta Bioenerget. 1277, 35-60. doi: 10.1016/S0005-2728(96)00102-8

Seo, E.-Y., Nam, J., Kim, H.-S., Park, Y.-H., Hong, S. M., Lakshman, D., et al. (2014). Selective interaction between chloroplast $\beta$-ATPase and TGB1 $L_{88}$ retards severe symptoms caused by alternanthera mosaic virus infection. Plant Pathol. J. 30, 58-67. doi: 10.5423/PPJ.OA.09.2013.0097

Seyfferth, C., and Tsuda, K. (2014). Salicylic acid signal transduction: the initiation of biosynthesis, perception and transcriptional reprogramming. Front. Plant Sci. 5:697. doi: 10.3389/fpls.2014.00697

Shalla, T. A. (1964). Assembly and aggregation of tobacco mosaic virus in tomato leaflets. J. Cell Biol. 21, 253-264. doi: 10.1083/jcb.21.2.253

Shalla, T. A. (1968). Virus particles in chloroplasts of plants infected with the U5 strain of tobacco mosaic virus. Virology 35, 194-203. doi: 10.1016/00426822(68) $90260-2$

Shalla, T. A., Petersen, L. J., and Giunchedi, L. (1975). Partial characterization of virus-like particles in chloroplasts of plants infected with the U5 strain of TMV. Virology 66, 94-105. doi: 10.1016/0042-6822(75)90181-6

Shi, B., Lin, L., Wang, S., Guo, Q., Zhou, H., Rong, L., et al. (2016). Identification and regulation of host genes related to Rice stripe virus symptom production. New Phytol. 209, 1106-1119. doi: 10.1111/nph.13699

Shimizu, T., Satoh, K., Kikuchi, S., and Omura, T. (2007). The repression of cell wall- and plastid-related genes and the induction of defense-related genes in rice plants infected with rice dwarf virus. Mol. Plant-Microbe Interact 20, 247-254. doi: 10.1094/mpmi-20-3-0247

Shimura, H., Pantaleo, V., Ishihara, T., Myojo, N., Inaba, J.-,i., Sueda, K., et al. (2011). A viral satellite RNA induces yellow symptoms on tobacco by targeting a gene involved in chlorophyll biosynthesis using the RNA silencing machinery. PLoS Path. 7:e1002021. doi: 10.1371/journal.ppat.1002021

Shintaku, M. H., Zhang, L., and Palukaitis, P. (1992). A single amino acid substitution in the coat protein of cucumber mosaic virus induces chlorosis in tobacco. Plant Cell 4, 751-757. doi: 10.1105/tpc.4.7.751

Shi, Y., Chen, J., Hong, X., Chen, J., and Adams, M. J. (2007). A potyvirus P1 protein interacts with the Rieske Fe/S protein of its host. Mol. Plant Pathol. 8, 785-790. doi: 10.1111/j.1364-3703.2007.00426.x

Smith, N. A., Eamens, A. L., and Wang, M.-B. (2011). Viral small interfering RNAs target host genes to mediate disease symptoms in plants. PLoS Path. 7:e1002022. doi: 10.1371/journal.ppat.1002022

Sui, C., Fan, Z., Wong, S.-M., and Li, H. (2006). Cloning of cDNAs encoding the three subunits of oxygen evolving complex in Nicotiana benthamiana and gene expression changes in tobacco leaves infected with tobacco mosaic virus. Physiol. Mol. Plant Pathol. 68, 61-68. doi: 10.1016/j.pmpp.2006.06.003

Sun, X., Li, Y., Shi, M., Zhang, N., Wu, G., Li, T., et al. (2013). In vitro binding and bimolecular fluorescence complementation assays suggest an interaction between tomato mosaic virus coat protein and tobacco chloroplast ferredoxin I. Arch. Virol. 158, 2611-2615. doi: 10.1007/s00705-013-1778-4

Suzuki, M., Kuwata, S., Masuta, C., and Takanami, Y. (1995). Point mutations in the coat protein of cucumber mosaic virus affect symptom expression and virion accumulation in tobacco. J. Gen. Virol. 76, 1791-1799. doi: 10.1099/00221317-76-7-1791

Takahashi, H., and Ehara, Y. (1992). Changes in the activity and the polypeptide composition of the oxygen-evolving complex in photosystem II of tobacco leaves infected with cucumber mosaic virus strain Y. Mol. Plant-Microbe Interact 5, 269-272. doi: 10.1094/MPMI-5-269

Takahashi, H., Ehara, Y., and Hirano, H. (1991). A protein in the oxygen-evolving complex in the chloroplast is associated with symptom expression on tobacco 
leaves infected with cucumber mosaic virus strain Y. Plant Mol. Biol. 16, 689-698. doi: 10.1007/BF00023433

Takanami, Y. (1981). A striking change in symptoms on cucumber mosaic virusinfected tobacco plants induced by a satellite RNA. Virology 109, 120-126. doi: 10.1016/0042-6822(81)90476-1

Thines, B., Katsir, L., Melotto, M., Niu, Y., Mandaokar, A., Liu, G., et al. (2007). JAZ repressor proteins are targets of the SCFCOI1 complex during jasmonate signalling. Nature 448, 661-665. doi: 10.1038/nature05960

Tomlinson, J. A., and Webb, M. J. W. (1978). Ultrastructural changes in chloroplasts of lettuce infected with beet western yellows virus. Physiol. Plant Pathol. 12, 13-18. doi: 10.1016/0048-4059(78)90014-0

Torrance, L., Cowan, G. H., Gillespie, T., Ziegler, A., and Lacomme, C. (2006). Barley stripe mosaic virus-encoded proteins triple-gene block 2 and $\gamma \mathrm{b}$ localize to chloroplasts in virus-infected monocot and dicot plants, revealing hitherto-unknown roles in virus replication. J. Gen. Virol. 87, 2403-2411. doi: 10.1099/vir.0.81975-0

Torres, M. A., Jones, J. D. G., and Dangl, J. L. (2006). Reactive oxygen species signaling in response to pathogens. Plant Physiol. 141, 373-378. doi: 10.1104/pp.106.079467

Turner, J. G., Ellis, C., and Devoto, A. (2002). The jasmonate signal pathway. Plant Cell 14(suppl. 1), S153-S164. doi: 10.1105/tpc.000679

Tu, Y., Jin, Y., Ma, D., Li, H., Zhang, Z., Dong, J., et al. (2015). Interaction between PVY HC-Pro and the $\mathrm{NtCF}_{1} \beta$-subunit reduces the amount of chloroplast ATP synthase in virus-infected tobacco. Sci. Rep. 5:15605. doi: 10.1038/srep15605

Ushiyama, R., and Matthews, R. E. F. (1970). The significance of chloroplast abnormalities associated with infection by turnip yellow mosaic virus. Virology 42, 293-303. doi: 10.1016/0042-6822(70)90273-4

Waliullah, S., Mochizuki, T., Sekine, K.-T., Atsumi, G., Ali, M. E., Yaeno, T., et al. (2014). Artificial induction of a plant virus protein in transgenic tobacco provides a synchronous system for analyzing the process of leaf chlorosis. Physiol. Mol. Plant Pathol. 88, 43-51. doi: 10.1016/j.pmpp.2014.08.005

Wang, B., Hajano, J. U., Ren, Y., Lu, C., and Wang, X. (2015). iTRAQ-based quantitative proteomics analysis of rice leaves infected by Rice stripe virus reveals several proteins involved in symptom formation. Virol. J. 12, 99. doi: 10.1186/s12985-015-0328-y

Wang, D., Amornsiripanitch, N., and Dong, X. (2006). A genomic approach to identify regulatory nodes in the transcriptional network of systemic acquired resistance in plants. PLoS Pathog. 2:e123. doi: 10.1371/journal.ppat.0020123

Wasternack, C. (2007). Jasmonates: an update on biosynthesis, signal transduction and action in plant stress response, growth and development. Ann. Bot. 100, 681-697. doi: 10.1093/aob/mcm079

Wasternack, C., and Hause, B. (2013). Jasmonates: biosynthesis, perception, signal transduction and action in plant stress response, growth and development. An update to the 2007 review in Annals of Botany. Ann. Bot. 111, 1021-1058. doi: $10.1093 / \mathrm{aob} / \mathrm{mct} 067$

Wei, T., Huang, T.-S., McNeil, J., Laliberté, J.-F., Hong, J., Nelson, R. S., et al. (2010). Sequential recruitment of the endoplasmic reticulum and chloroplasts for plant potyvirus replication. J. Virol. 84, 799-809. doi: 10.1128/JVI. 01824-09

Wei, T., Zhang, C., Hou, X., Sanfaçon, H., and Wang, A. (2013). The SNARE protein Syp71 is essential for turnip mosaic virus infection by mediating fusion of virus-induced vesicles with chloroplasts. PLoS Path. 9:e1003378. doi: 10.1371/journal.ppat.1003378

White, J. A., and Sehgal, O. P. (1993). Ultrastructure of tobacco ringspot virusinduced local lesions in lima bean leaves. J. Phytopathol. 138, 177-188. doi: 10.1111/j.1439-0434.1993.tb01376.x

Wieringabrants, D. H. (1981). The role of the epidermis in virus-induced local lesions on cowpea and tobacco-leaves. J. Gen. Virol. 54, 209-212. doi: 10.1099/0022-1317-54-1-209

Wildermuth, M. C., Dewdney, J., Wu, G., and Ausubel, F. M. (2001). Isochorismate synthase is required to synthesize salicylic acid for plant defence. Nature 414, 562-565. doi: $10.1038 / 35107108$

Wiltshire, G. H. (1956). The effect of darkening on the susceptibility of plants to infection with viruses. Ann. Appl. Biol. 44, 233-248. doi: 10.1111/j.17447348.1956.tb02119.x

Wisniewski, L. A., Powell, P. A., Nelson, R. S., and Beachy, R. N. (1990). Local and systemic spread of tobacco mosaic virus in transgenic tobacco. Plant Cell 2, 559-567. doi: 10.1105/tpc.2.6.559
Wolf, S., Lucas, W. J., Deom, C. M., and Beachy, R. N. (1989). Movement protein of tobacco mosaic virus modifies plasmodesmatal size exclusion limit. Science 246, 377-379. doi: 10.1126/science.246.4928.377

Wu, L., Wang, S., Chen, X., Wang, X., Wu, L., Zu, X., et al. (2013). Proteomic and phytohormone analysis of the response of maize (Zea mays L.) seedlings to sugarcane mosaic virus. PLOS ONE 8:e70295. doi: 10.1371/journal.pone.0070295

Xiang, Y., Kakani, K., Reade, R., Hui, E., and Rochon, D. A. (2006). A 38-aminoacid sequence encompassing the arm domain of the cucumber necrosis virus coat protein functions as a chloroplast transit peptide in infected plants. J. Virol. 80, 7952-7964. doi: 10.1128/JVI.00153-06

Xiao, Y., Savchenko, T., Baidoo, E. E. K., Chehab, W. E., Hayden, D. M., Tolstikov, V., et al. (2012). Retrograde signaling by the plastidial metabolite MEcPP regulates expression of nuclear stress-response genes. Cell 149, 1525-1535. doi: 10.1016/j.cell.2012.04.038

Xu, J., and Feng, M. (1998). Ultrastructural differences of RMV and TMV infected Nicotiana tabacum mesophyll cells for distinguishing virus strains. Acta Microbiol. Sin. 38, 422-427.

Xu, Y., and Zhou, X. (2012). Role of Rice stripe virus NSvc4 in cell-to-cell movement and symptom development in Nicotiana benthamiana. Front. Plant Sci. 3:269. doi: 10.3389/fpls.2012.00269

Yang, J., Zhang, F., Li, J., Chen, J.-P., and Zhang, H.-M. (2016). Integrative analysis of the microRNAome and transcriptome illuminates the response of susceptible rice plants to rice stripe virus. PLoS ONE 11:e0146946. doi: 10.1371/journal.pone. 0146946

Yan, J., Zhang, C., Gu, M., Bai, Z., Zhang, W., Qi, T., et al. (2009). The Arabidopsis CORONATINE INSENSITIVE1 protein is a jasmonate receptor. Plant Cell 21, 2220-2236. doi: 10.1105/tpc.109.065730

Yan, S. L., Lehrer, A. T., Hajirezaei, M. R., Springer, A., and Komor, E. (2008). Modulation of carbohydrate metabolism and chloroplast structure in sugarcane leaves which were infected by sugarcane yellow leaf virus (SCYLV). Physiol. Mol. Plant Pathol. 73, 78-87. doi: 10.1016/j.pmpp.2009.02.004

Zarzyńska-Nowak, A., Jeżewska, M., Hasiów-Jaroszewska, B., and Zielińska, L. (2015). A comparison of ultrastructural changes of barley cells infected with mild and aggressive isolates of barley stripe mosaic virus. J. Plant Dis. Protect 122, 153-160. doi: 10.1007/bf03356545

Zechmann, B., Müller, M., and Zellnig, G. (2003). Cytological modifications in zucchini yellow mosaic virus (ZYMV)-infected Styrian pumpkin plants. Arch. Virol. 148, 1119-1133. doi: 10.1007/s00705-003-0005-0

Zhang, C., Liu, Y., Sun, X., Qian, W., Zhang, D., and Qiu, B. (2008). Characterization of a specific interaction between IP-L, a tobacco protein localized in the thylakoid membranes, and tomato mosaic virus coat protein. Biochem. Biophys. Res. Commun. 374, 253-257. doi: 10.1016/j.bbrc.2008. 07.010

Zhao, J., Liu, Q., Zhang, H., Jia, Q., Hong, Y., and Liu, Y. (2013). The RubisCO small subunit is involved in Tobamovirus movement and Tm-22-mediated extreme resistance. Plant Physiol. 161, 374-383. doi: 10.1104/pp.112.209213

Zhao, W., Yang, P., Kang, L., and Cui, F. (2016). Different pathogenicities of Rice stripe virus from the insect vector and from viruliferous plants. New Phytol. 210, 196-207. doi: 10.1111/nph.13747

Zheng, X.-Y., Spivey, N. W., Zeng, W., Liu, P.-P., Fu, Z. Q., Klessig, D. F., et al. (2012). Coronatine promotes Pseudomonas syringae virulence in plants by activating a signaling cascade that inhibits salicylic acid accumulation. Cell Host Microbe 11, 587-596. doi: 10.1016/j.chom.2012.04.014

Zurbriggen, M. D., Carrillo, N., and Hajirezaei, M. R. (2010). ROS signaling in the hypersensitive response: when, where and what for? Plant Signal. Behav. 5, 393-396. doi: 10.4161/psb.5.4.10793

Conflict of Interest Statement: The authors declare that the research was conducted in the absence of any commercial or financial relationships that could be construed as a potential conflict of interest.

Copyright (๑) 2016 Zhao, Zhang, Hong and Liu. This is an open-access article distributed under the terms of the Creative Commons Attribution License (CC BY). The use, distribution or reproduction in other forums is permitted, provided the original author(s) or licensor are credited and that the original publication in this journal is cited, in accordance with accepted academic practice. No use, distribution or reproduction is permitted which does not comply with these terms. 